\title{
Mycotoxin Contamination of Beverages Obtained from Tropical Crops
}

\author{
Fabio Granados-Chinchilla ${ }^{1, * \mathbb{C}}$, Mauricio Redondo-Solano ${ }^{2}$ and Daniela Jaikel-Víquez ${ }^{3}$ \\ 1 Centro de Investigación en Nutrición Animal (CINA), Universidad de Costa Rica, \\ Ciudad Universitaria Rodrigo, San José 11501-2060, Costa Rica \\ 2 Centro de Investigación en Enfermedades Tropicales (CIET) and Sección de Microbiología de Alimentos, \\ Departamento de Microbiología e Inmunología, Facultad de Microbiología, Universidad de Costa Rica, \\ San José 11501-2060, Costa Rica; mauricio.redondosolano@ucr.ac.cr \\ 3 Centro de Investigación en Enfermedades Tropicales (CIET) and Sección de Micología Médica, \\ Departamento de Microbiología e Inmunología, Facultad de Microbiología, Universidad de Costa Rica, \\ San José 11501-2060, Costa Rica; daniela.jaikelviquez@ucr.ac.cr \\ * Correspondence: fabio.granados@ucr.ac.cr; Tel.: +506-2511-2028; Fax: +506-2234-2415
}

Received: 1 October 2018; Accepted: 2 November 2018; Published: 8 November 2018

\begin{abstract}
This review is mainly centered on beverages obtained from tropical crops, including tea, nut milk, coffee, cocoa, and those prepared from fruits. After considering the epidemiological data found on the matrices above, the focus was given to recent methodological approaches to assess the most relevant mycotoxins. Aspects such as singularities among the mycotoxin and the beverage in which their were found, and the economic effects and repercussions that the mycotoxin-tainted ingredients have on the beverage industry were pointed out. Finally, the burden of their consumption through beverages, including risk and health effects on humans, was addressed as well.
\end{abstract}

Keywords: Latin American beverages; mycotoxins; chromatographic methods; legislation; tropical beverages

\section{Introduction}

\subsection{General Remarks for Mycotoxins}

Mycotoxins are toxic secondary metabolites produced by aerobic, mycelial, microscopic fungi, especially from the genera Aspergillus, Fusarium, and Penicillium [1-3] (Figure 1A-F); these compounds may cause adverse health effects (e.g., hepatotoxicity, nephrotoxicity, neurotoxicity, and immunotoxicity) in humans and animals $[4,5]$. Toxic effects in plants related with mycotoxins and mechanisms governing endophytic plant colonization and disease have been described, as well [3]. Among multiple mycotoxin congeners characterized, aflatoxins (AFs), citrinin (CIT), patulin (PAT), penicillic acid (PA), tenuazonic acid (TEA), ochratoxin A (OTA), cytochalasins, deoxynivalenol $(\mathrm{DON})$, fumonisins (FBs), fusarin C (FC), fusaric acid (FA), and zearalenone (ZEA) are considered the most common fungal contaminants in plant tissue (Figure 1) [3]. For humans, the majority of mycotoxicoses result from eating contaminated foods, and the symptoms depend on the type of mycotoxin, the amount and duration of the exposure, and certain inherent factors related to the patient such as age, sex, health and dietary status [4]. Under appropriate conditions (e.g., available genes in a strain, nature of the crop, moisture, and temperature), harvest and postharvest fungi colonization and mycotoxin production are feasible; this is particularly crucial for beverages made from tropical products such as different varieties of tea, coffee, cocoa, and fruits. Tropical products used as raw material for the production of drinks can be infected with toxigenic molds during crop growth, harvest, storage, or processing [6]. Mycotoxin accumulation in tropical crops may be relevant, 
as these commodities are generally grown under relatively warm temperatures and high-humidity conditions [7]. Even though chemical (including biodetoxification) [8], biological [9], and physical (e.g., roasting, and shelling) detoxification or toxin reduction operations are possible, toxins can still reach the final consumer as they are relatively resistant to harsh processing conditions and are seldom spread homogenously across products. Hence, contamination of beverages (e.g., tea, coffee, and juices) is not uncommon. Adverse effects of these toxins on human and animal health have been documented, and particular interest has been drawn to the topic [10-17]. In general, beverages made from tropical products are widely consumed around the world and beverage overall quality depends on the raw materials used to prepare said drinks. However, especially in low-income countries, where toxin analysis may not be as widespread, or it is limited, unregulated raw materials may be processed. For example, traditionally prepared African beverages have recently been subject of study since grains from which these beverages are made were generally found to be heavily contaminated with mycotoxins [18]. Furthermore, mycotoxins may cause adverse economic effects, as they can hamper the international trading of contaminated products and eventually result in food waste $[19,20]$. In fact, some conservative estimates place the incidence of illness related to aflatoxins at $1 \%$, in low and middle-income countries, which translate to ca. 2 billion USD in health expenditures [21].

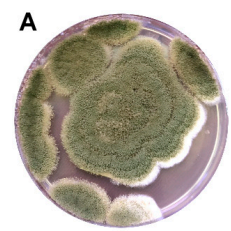

D

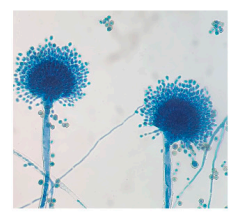

$\mathbf{G}$

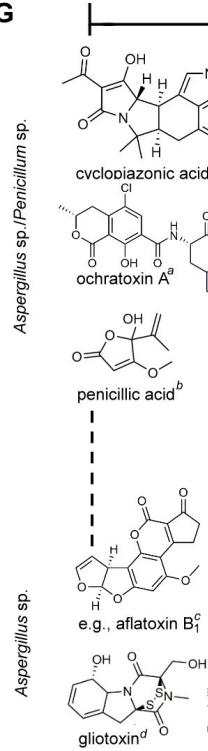

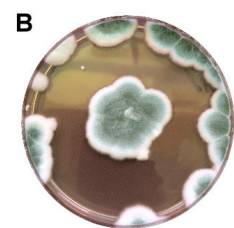

E
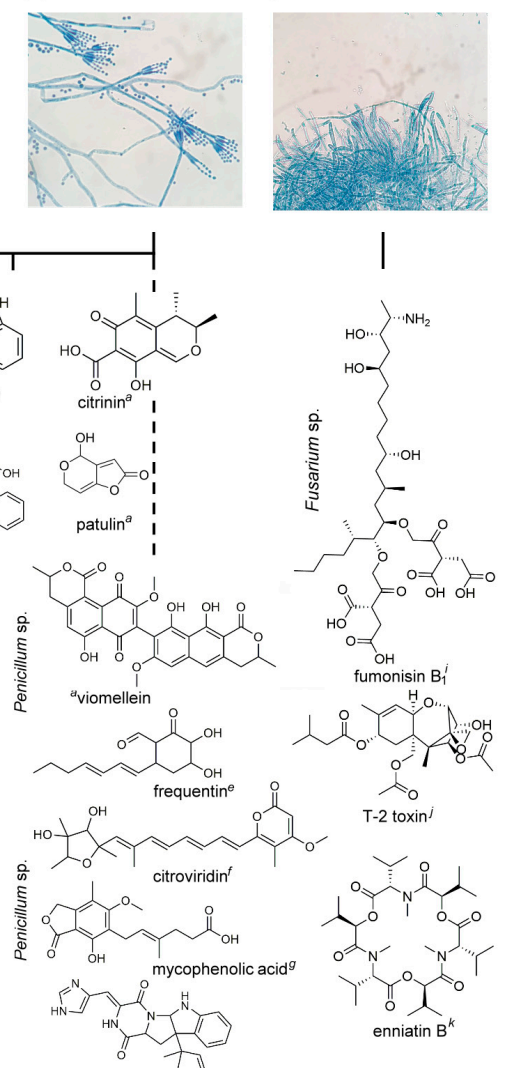

roquefortin $\mathrm{C}^{h}$
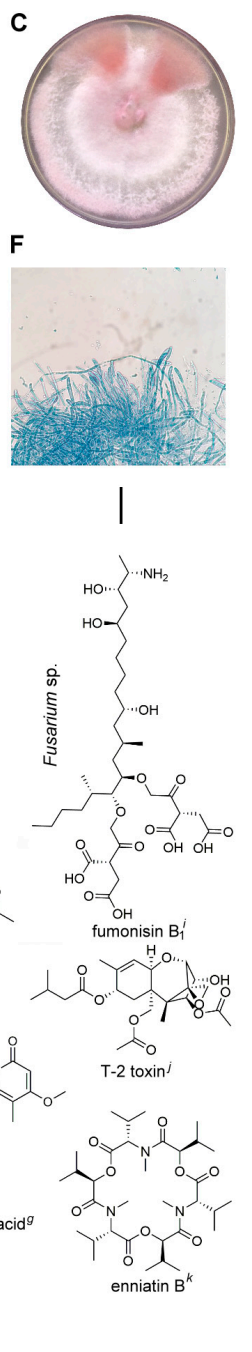

Figure 1. Colonies of mycotoxigenic fungi grown in Sabouraud Dextrose Agar and their respective microscopic images after staining with lactophenol cotton blue. (A,D) Aspergillus flavus; (B,E) Penicillium sp.; (C,F) Fusarium solani. (G). Structures of model mycotoxins produced by the aforementioned fungal species. ${ }^{a}$ benzopyrans; ${ }^{b}$ isopropylidene tetronic acid; ${ }^{c}$ difuranocoumarin; ${ }^{d}$ epipolythiodioxopiperazine; 
${ }^{e}$ carbaldehyde; ${ }^{f}$ pyranone; $g$ meroterpenoid; ${ }^{h}$ diketopiperazine; ${ }^{i}$ monoterpene; ${ }^{j}$ trichothecene/ sesquiterpenoid; ${ }^{k}$ cyclic depsipeptide.

\subsection{Consumption Data for Tropical Beverages and Related Products}

Substantial evidence has been found to suggest that there is a link between mycotoxin occurrence, exposure, and food consumption patterns [22]; therefore, this section deals with the production and consumption of the leading tropical beverages (Table 1). Outside Europe and the Americas, where coffee is preferred, tea is a favorite and relevant beverage. The uppermost tea consuming countries, including mate (a traditional caffeine-rich infused drink made from dry leaves from yerba mate, Ilex paraguariensis A. St.-Hill), are South American [23] (Table 1). However, other countries have high consumption patterns as well. In Iran, for example, a country with an estimated consumption of $1.83 \mathrm{~kg}$ per capita per year, black tea is preferred, and it is estimated that the average amount of tea consumed is $1243 \pm 530 \mathrm{~mL} \mathrm{day}^{-1}$ [24]. In the United States, iced-tea drinks are preferred, and Europeans are more inclined toward drinking flavored fruit teas; "foamy" tea is primarily consumed in Taiwan, while herbal tea is favored in the United States, China, Japan, and Thailand, and ready-to-drink tea is consumed chiefly in Japan, USA, and Taiwan. On 2016, a consumption structure was reported to be $80.0,69.2,36.0$, and $10.3 \%$ of black tea, 16.0, 7.1, 39.0, and 53.3\% of green tea for the United States, the United Kingdom, Canada, and China, respectively [25]. Fruit or herbal teas are relevant in Canada and the United Kingdom with a 27.0 and $12.2 \%$ consumption rate, respectively [25].

On the other hand, coffee is considered one of the most important hot beverages. The 2016-2017 world coffee harvest amounted to a total of 157.43 million $60 \mathrm{~kg}$ bags. The foremost coffee consumers are Nordic countries (Table 1), while in Latin America, the primary consumers are Brazil (5.92) and Costa Rica (5.14 kg per capita per year) [26]. However, concerns about the adverse effects of caffeine on human health have had an impact on coffee-drinking frequency and quantity. Regarding chocolate, the consumption is also relatively high, ranging from $1.20 \times 10^{-1}$ (China) to $8.98 \times 10^{0}$ (Switzerland) $\mathrm{kg}$ per person per year $[27,28]$ (Table 1 ). For example, Panamanian populations have been reported to reach consumption rates as high as ca. $8.87 \times 10^{2} \mathrm{~mL}$ of cocoa-based beverages daily [28]. Though benefits of cocoa and chocolate consumption are numerous [29], mycotoxin-burdened products may counter these virtues.

Table 1. Top producing and consuming countries for tea, coffee, chocolate and cocoa, and dried and fresh fruit.

\begin{tabular}{|c|c|c|c|c|}
\hline & \multicolumn{2}{|c|}{ Consumption } & \multicolumn{2}{|c|}{ Production Export Value } \\
\hline \multicolumn{5}{|c|}{ Tea (including mate) $[23,25]$} \\
\hline Rank & Country & kg per capita per year & Country & Metric tons \\
\hline 1 & Paraguay & 12.22 & China & $2,414,802$ \\
\hline 2 & Uruguay & 9.66 & India & $1,252,174$ \\
\hline 3 & Argentina & 6.05 & Kenya & 473,000 \\
\hline 4 & Kenya & 3.24 & Sri Lanka & 349,308 \\
\hline 5 & Gambia & 3.22 & Turkey & 243,000 \\
\hline \multicolumn{5}{|c|}{ Coffee [26] } \\
\hline Rank & Country & $\mathrm{kg}$ per capita per year & Country & Thousand $60 \mathrm{~kg}$ bags \\
\hline 1 & Finland & 12.2 & Brazil & 52,735 \\
\hline 2 & Sweden & 10.1 & Vietnam & 29,500 \\
\hline 3 & Norway & 8.9 & Colombia & 14,000 \\
\hline 4 & Austria & 7.8 & Indonesia & 10,902 \\
\hline 5 & Switzerland & 7.6 & Ethiopia & 7650 \\
\hline \multicolumn{5}{|c|}{ Chocolate $[27,28]$} \\
\hline Rank & Country & kg per capita per year & Country & Thousand USD \\
\hline 1 & Switzerland & 8.98 & Cote d'Ivoire & $2,595,897$ \\
\hline 2 & Germany & 7.89 & Ghana & $1,090,910$ \\
\hline 3 & Ireland & 7.39 & Indonesia & $1,087,485$ \\
\hline 4 & United Kingdom & 7.39 & Nigeria & 599,000 \\
\hline 5 & Norway & 6.62 & Cameroon & 540,281 \\
\hline
\end{tabular}


Table 1. Cont.

\begin{tabular}{ccccc}
\hline \multicolumn{2}{c}{ Consumption } & \multicolumn{2}{c}{ Production Export Value } \\
\hline & Tropical beverage crops, fruits, and sugar [30] \\
\hline & Country & Million USD & Country & $\begin{array}{c}\text { Million USD (percentage of the } \\
\text { total agricultural products traded) }\end{array}$ \\
\hline 1 & United States & 2402 & Brazil & $16,466(19.6)$ \\
2 & Mexico & 3071 & Colombia & $2951(45.8)$ \\
3 & Spain & 3373 & Ecuador & $2782(56.5)$ \\
4 & China & 3386 & Vietnam & $2678(26.5)$ \\
5 & Germany & 4360 & Guatemala & $2403(44.2)$ \\
6 & Netherlands & 4708 & Ivory Coast & $2276(48.5)$ \\
7 & United Kingdom & 8602 & Costa Rica & $2015(50.7)$ \\
\hline
\end{tabular}

Lastly, Central and South American countries are the principal producers of tropical beverage crops, fruits, and sugar [30] (Table 1). Additionally, consumer-wise, there has been a shift from nutrient-deficient, added-sugar and high fructose-containing beverages to more natural fruits and herbal infusions due to the prevalence of obesity [31,32]. Natural fruit juice drinking has changed the dynamics of the still drinks industry and consumption patterns. It is estimated that $2.35 \times 10^{1}$ million liters of juices and $1.70 \times 10^{1}$ million liters of nectar beverages were consumed globally in 2009; this represented an increase of 30.2\% since 2003 [33]. Also, within the tropical juices category, the number of manufactured products and the consumption rates may vary among the crops. Pineapple juice is considered the most important fruit used for tropical juice production as the global business is estimated at ca. $2.50 \times 10^{5}$ tons per year. The consumption pattern for pineapple juice is mostly driven by the US and the European market, where people ingest more than $2.50 \times 10^{1} \mathrm{~L}$ per year [34].

\subsection{Technological Processing and Mycotoxin Reduction}

Good agricultural and manufacturing practices could be considered the best intervention to avoid mycotoxin contamination of beverages. Typically, the raw materials used for beverage production may be contaminated at the field (preharvest and harvest operations) or during storage. Selection of good quality material for processing is the first step to prevent further contamination; this is especially true in the case of fruit juices as ripened fruits are selected for processing [35]. For some beverages, the removal of rotten material or food parts with fungal contamination is a crucial step to reduce pollution in the final product [36]. During storage, the use of low temperatures and modified atmospheres is considered an essential control for fungal growth on the raw material. Storage facilities are considered the main factor to prevent contamination from the environment. Poor stowing conditions of the raw materials or even the finished product can have an incidence in the process downstream recontamination. Availability of facilities with proper infrastructure in tropical countries with developing economies may be limited, leading to the open storage of products intended for juice production [35]. On the other hand, processing techniques may reduce, to some extent, the mycotoxin level of contamination at the industry level (e.g., removing hulls from almonds), but unit operations seldom affect the former concentration. For example, the use of additives and thermal treatment may reduce the levels of discrete mycotoxins in beverages [35]. However, there is an inherited expense when additional stages (physical, chemical or otherwise) in food processing (including drinks) are used to reduce mycotoxin contamination. These procedures, however, are usually already part of the beverage-obtaining process, but they are not typically considered if they are not required to get the product. Available treatments and the consequences of introducing such steps have already been detailed elsewhere [37]. To obtain a beverage as a final product, usually, the raw material will have to undergo several operating units and technological steps; plant designs for both pineapple juice (Figure 2A) and cocoa (Figure 2B) are presented to help the reader relate to the topic.

Even though processing may have an impact on mycotoxin stability, there are few studies related with beverages made from tropical crops. For example, the influence of industrial treatments on OTA content in cocoa bean processing has been investigated [38]. The authors concluded that roasting, 
shelling and additive addition, significantly decreased OTA levels in cocoa finished products. On the other hand, Hao et al. [39] also observed that PAT content decreases in different apple juice-based products (including a mixture with pineapple) after processing with high-pressure technology; the authors noted a correlation between mycotoxin degradation with high pressure and the number of sulfhydryl groups in the juice.

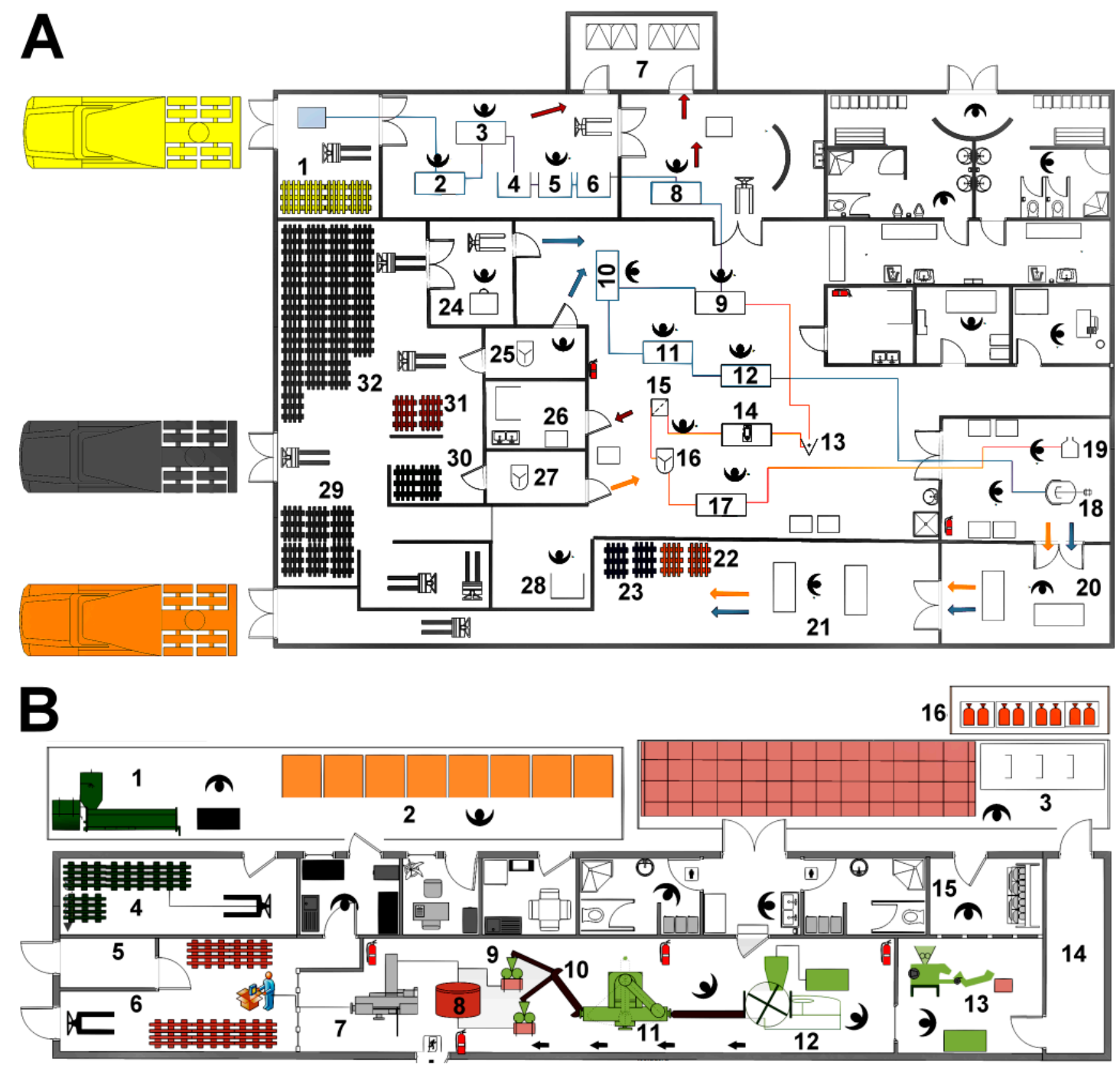

Figure 2. Existent Costa Rican factory layout, representing product lines for (A) Pineapple beverage and canned fruit facility: 1. Receipt 2. Fruit selection 3. Decrowning 4. Wash 5. Disinfection 6. Draining 7. Waste disposal 8. Peel and coring 9. Chopping 10. Canning 11. Juice addition 12. Can sealing 13. Crusher 14. Hydraulic press 15. Filter 16. Mixer 17. Bottling 18. Autoclave 19. Cooking pot 20. Cooling area 21. Labeling 22. Pineapple juice bottles 23. Canned apple chunks 24. Gas injection 25. Syrup formulation/mixer 26. Cleaning 27. Pineapple juice formulation 28. Bottle disinfection 29. Empty bottles 30. Citric acid 31. Sugar 32. Empty cans. Workflow for $\longrightarrow$ Pineapple juice production $\longrightarrow$ Canned pineapple chunks production $\longrightarrow$ Waste disposal and treatment; and (B) Chocolate: 1. Receipt and depulping 2. Fermentation 3. Drying (greenhouse) 4. Raw material storage house 5. Packaging material storage 6. Packaging 7. Baler 8. Storage tank 9. Rectification 10. Elevator 11. Mill 12. Toaster 13. Dehuller 14. Fuel and maintenance material storage 15. Cocoa dry bean storage 16. Waste.

Other novel non-thermal techniques such as ozone decontamination or irradiation may have the potential to reduce mycotoxin levels in tropical juices [40,41]. As noted before, the availability of these technologies may be limited as tropical beverages are typically produced in countries with developing 
economies. Finally, few articles have described the filamentous fungal contamination and its behavior from the raw material or ingredients to the finalized product. Some production lines have been investigated in their entirety including cocoa [42], tomato [43], beer [44], and dairy products [45,46]. Contaminants found in dairy products are relevant to the beverage industry not only because of milk consumption (in all its presentations, Latin America and the Caribbean dairy consumption is estimated at $7.84 \times 10^{1} \mathrm{~kg} \mathrm{hd}^{-1}$ day $^{-1}$ ) [47,48], but because of the use of whey as an ingredient for novel functionalized ready-to-drink beverages that incorporate tropical ingredients [49-51]. These types of beverages have been developed worldwide, e.g., lemon and strawberry drinks in India and Brazil, respectively $[52,53]$.

\section{Common Drinks Produced in the Tropics Subjected to Mycotoxin Contamination}

\subsection{Tea (Including Mate)}

Tea is among the most common drinks, and it is an essential product in the global market $[54,55]$. Tea consumption is a growing trend within the middle class and the urbanized population of many emerging and developing markets [56,57]. Nowadays, commercial presentations range from green to white to fruit-based infused teas. Herbs from which infused drinks are prepared enjoy popularity, as they are considered to function as both medicine and for food purposes [58].

\subsubsection{Mycotoxin Contamination and Fungal Charge Found in Tea}

In recent years, medicinal plants have gained interest as they may serve as a possible source of mycotoxin contamination [59]. $\mathrm{AFB}_{1}, \mathrm{AFB}_{2}, \mathrm{AFG}_{1}, \mathrm{AFG}_{2}, \mathrm{OTA}, \mathrm{ZEA}, \mathrm{FB} 1, \mathrm{CIT}$, DON, nivalenol (NIV), neosolaniol (NEO), fusarenone- $X$, and T-2 toxin have all been detected in medicinal herbs, including Latin American products [55]. Medicinal plants and herbs are noteworthy in this section, since they are used as materials for infused drinks [60]. A Chinese research group analyzed tea and found negligible risk regarding $\mathrm{FB}_{1}$ and $\mathrm{T}-2$ toxin, but a considerable number of samples did surpass established thresholds for $\mathrm{AFB}_{1}$ and DON (Table 2) [61].

Processing-wise, tea is classified into six categories: green (unfermented), white (slightly fermented), yellow (partly fermented), Oolong (semi-fermented), black (fully fermented) and dark tea (post-fermented) [62]. Then, in the case of tea, processing has a profound effect on the initial fungal communities that can colonize herbs, and it will determine those strains that may persist during and after fermentation. At least one research group has focused on describing the changes in fungal communities during processing of Fu Brick, another post-fermented tea [63,64]. In one case, Aspergillus dominated the manufacturing process for this product, increasing its presence from 65.13 to $93.58 \%$ [63]. More recently, Cyberlindnera was found to also be a significant protagonist during processing [64]. Other Asian fermented (pickled) teas, produced from the leaves of Camellia sinensis var. assamica Pierre, and processed by anaerobic fermentation, include Miang (Thailand) [65], Laphet (Myanmar) [66], and Goichi-cha (Japan) [67]. Pu-Erh tea is another exciting example as it is also considered a "post-fermented" tea [54]. Leaves are fermented using mainly Aspergillus niger [54]. Hass and coworkers found no AF or FB contamination in the Pu-Erh tea samples, while fungal counts ranged from $1.0 \times 10^{1}$ to $2.6 \times 10^{6} \mathrm{CFU} \mathrm{g}{ }^{-1}$ of tea. The most prevalent fungi included Aspergillus, Penicillium, and Mucorales [54]. On the other hand, Matei and coworkers found a high fungal charge in four types of tea: rosehip, sweet basil, black and nettle teas (ranging from $7.82 \times 10^{3}$ to $1.92 \times 10^{5} \mathrm{CFU} \mathrm{g}^{-1}$ ), surpassing the $1.00 \times 10^{2} \mathrm{CFU} \mathrm{g}^{-1}$ legislative threshold; some of the specimens were identified as Fusarium. Considerable levels of AF contamination were found $\left(n=7>10\right.$ and $\left.n=3>1.00 \times 10^{2} \mu \mathrm{g} \mathrm{kg}^{-1}\right)$ and a St. John's wort tea sample greatly exceeded the limits imposed by European legislation [60]. In contrast, Siddique and coworkers have found low fungal counts $\left(4 \times 10^{2}\right.$ to $\left.2 \times 10^{3} \mathrm{CFU} \mathrm{g}^{-1}\right)$ in several herbal samples and the authors associated this small microbial charge with the negligible concentrations of negligi found in some of the samples (i.e., $<9.00 \times 10^{-2} \mu \mathrm{g} \mathrm{kg}^{-1}$ ) [68]. 
Research based in Costa Rica examined the prevalence of OTA and AFs in several varieties of supermarket-available chamomile and mint teas. Relatively low contamination was found in the examined herbs. The analysis determined residues of OTA produced by Fusarium and Penicillium. OTA was present in greater quantities in the mint tea compared to the chamomile tea. No relationship between fungal counts and OTA contamination was found [69]. In yet another example, Kong and coworkers found higher ZEA concentrations in Coix seeds used to prepare a very popular tea in Korea [70]. Finally, a Spanish study examined herbal samples and found that sage leaves, chamomile flower, valerian root, senna leaves, and rhubarb were among the most mycotoxin-contaminated herbs. Co-contamination with OTA, FBs, AFs, ZEA, T-2, DON, and CIT was also observed [71].

No clear regulation for mycotoxins in herbal products (or drinks derivate thereof, i.e., tea or infusions) has been established. However, the maximum concentrations in similar products tend to be low; the European Community Regulation EC 1881/2006 stipulates that the maximum limits for spices are $5.0 \times 10^{0}$ and $1.0 \times 10^{1} \mu \mathrm{g} \mathrm{kg}{ }^{-1}$ for $\mathrm{AFB}_{1}$ and total $\mathrm{AFs}$ (i.e., the sum of the four different aflatoxin fractions), respectively. Other safety limits have been set to $4.00 \times 10^{3}, 1.00 \times 10^{3}, 1.00 \times 10^{2} \mu \mathrm{g} \mathrm{kg}^{-1}$ for $\mathrm{FB}, \mathrm{DON}$, and $\mathrm{T}-2$, respectively.

\subsubsection{Mycotoxin Transference Rate from Herbs to Infusions}

There is evidence that between 4.1 and $34.8 \%$ of OTA could be transferred to an already-prepared infusion [72]. Analogously, AF transfer from the herbs to the infusion has also been investigated. Considerable rates were found in five types of herbal medicines. Remarkably, despite being structurally related, a differential transference was found and calculated to be 7.26-115.36, 4.37-26.37 and 9.64- $47.68 \%$ for $\mathrm{AFG}_{2}, \mathrm{AFB}_{1}$, and $\mathrm{AFB}_{2}$, respectively [73].

\subsubsection{Yerba Mate}

Few papers have focused on yerba mate infusion, a favorite drink from South America. However, there is evidence of the presence of some Aspergillus sections, including Flavi, Nigri, Circumdati, and Fumigati [74]. In another study, 2072 aspergilli (78.9\% corresponding to section Nigri; $40 \%$ Aspergillus japonicus var. japonicus, $28 \%$ A. japonicus var. aculeatus, $16 \% A$. niger var. niger, $12 \%$ Aspergillus foetidus, $2 \%$ Aspergillus carbonarius, $2 \%$ A niger var. awamori) strains were isolated from 41 samples of yerba mate. In vitro production of OTA was observed in $1 \%$ of the strains. Additionally, they demonstrated not only fungal presence and growth, but also fungal tolerance to $\mathrm{pH}$ variations and survival even after treatment with elevated temperatures (i.e., boiling water) [75].

\subsubsection{The Relationship between Mycotoxins and Bioactive Compounds Found in Tea}

Mycotoxin accumulation has been associated negatively with bioactive components (i.e., 6-gingerol, 6-shogaol, 8-gingerol, and 10-gingerol), thus affecting the spice quality [76]. Dry ginger has been described as an adequate growth substrate for A. niger, A. flavus, P. citrinum, P. verrucosum, and Fusarium moniliforme [77]. Interestingly, epigallocatechin (a nutraceutical with antioxidant capacity widespread in plants, found in almond and present in relatively considerable quantities in green and black tea) has demonstrated a cytoprotective role against DON-induced damage in HT-29 cells (a human colon cancer cell line) [78]. A similar effect was observed in cytotoxicity induced by trichothecenes (TRC) [79].

\subsection{Nutmilk and Similar Beverages}

Several beverages are based on nuts and seeds; these ingredients may very well transfer mycotoxins to the final product; this is the case of the English-French origin almond-based orgeat syrup, which is used as a drink mixer. Nutmilk or "Horchata" is the name given to a series of aromatic traditional beverages based on several cereals, seeds or nuts, and spices. Diverse ingredients are used to prepare this type of beverage including tubers from Cyperus esculentus L. (tiger nut, ordinarily from West Africa, popular in Spain). Other variants include sesame seed (scented with vanilla and 
cinnamon, popular in Puerto Rico and Venezuela), almond, rice (spiced with cinnamon or Súchil flower [Plumeria rubra L.], popular in Mexico), coconut and cantaloupe seeds (Cucumis melo L.). In several Central American countries, the drink is prepared using the dried fruit from Crescentia cujete $\mathrm{L}$. Other ingredients may include ground cocoa, cinnamon, sesame seeds, nutmeg, tiger nuts, vanilla, ground peanuts, almonds, and cashews. On the other hand, an herbal infusion drink prepared in Ecuador called "Horchata lojana" is prepared with Aerva sanguinolenta (L.) Blume, Aloysia triphylla (L'Hér.) Britton, Aloysia citriodora (Lam.) Ortega ex Pers., Melissa officinalis L., mint, chamomile, and rose essence, among other things. Usually, this type of beverage is only found in artisanal food expenditures. Notwithstanding, horchata has become more popular, being subjected to commercialization, and it has grown relevant in several regions.

These ingredients and, thus, the beverages derived from them, are susceptible to mycotoxin contamination [80]. However, only a few papers have focused on the assessment of these products. For example, tiger nut-based soft drinks in Spanish and Belgian markets were assayed for $\mathrm{AFB}_{1}$, finding $n=1$ samples above the limit of detection of the method used by the researchers [81]. Similarly, Sebastiá and coworkers analyzed AFs in tiger nuts and tiger nut beverages. They examined the four different fractions of AFs, but total aflatoxin concentrations found ranged from 8.2 to $9.5 \mu \mathrm{g} \mathrm{kg}^{-1}$ and 4.6 to $6.4 \mathrm{\mu g} \mathrm{kg}^{-1}$ for tiger nuts and their beverages, respectively [82]. Peanuts, another primary ingredient in this type of nut-based drinks (and the popular among Andean people "chicha de maní" [83]), are continuously linked to fungal and toxin contamination [16]. Locally, we have demonstrated relatively high contamination for this crop (i.e., $21.8 \%$ prevalence) [84]. In regard to almonds, different authors have reported fungal contamination of this crop with Aspergillus, Penicillium, Rhizopus, Alternaria and Fusarium and, hence, its subsequent mycotoxin production, especially AF contamination [85]. Also, mycotoxigenic fungi-A. flavus, A. niger, and A. ochraceus-have been isolated from cinnamon [86,87]. Lamboni and coworkers isolated 150 strains of Aspergilli from cashews and assayed their mycotoxin production. Three mycotoxin groups were detected FBs, OTA and secalonic acids, indicating that these mycotoxins could occur in raw cashew nuts [88].

Table 2. Mycotoxin contamination found in herbal samples, nuts and nut-based beverages.

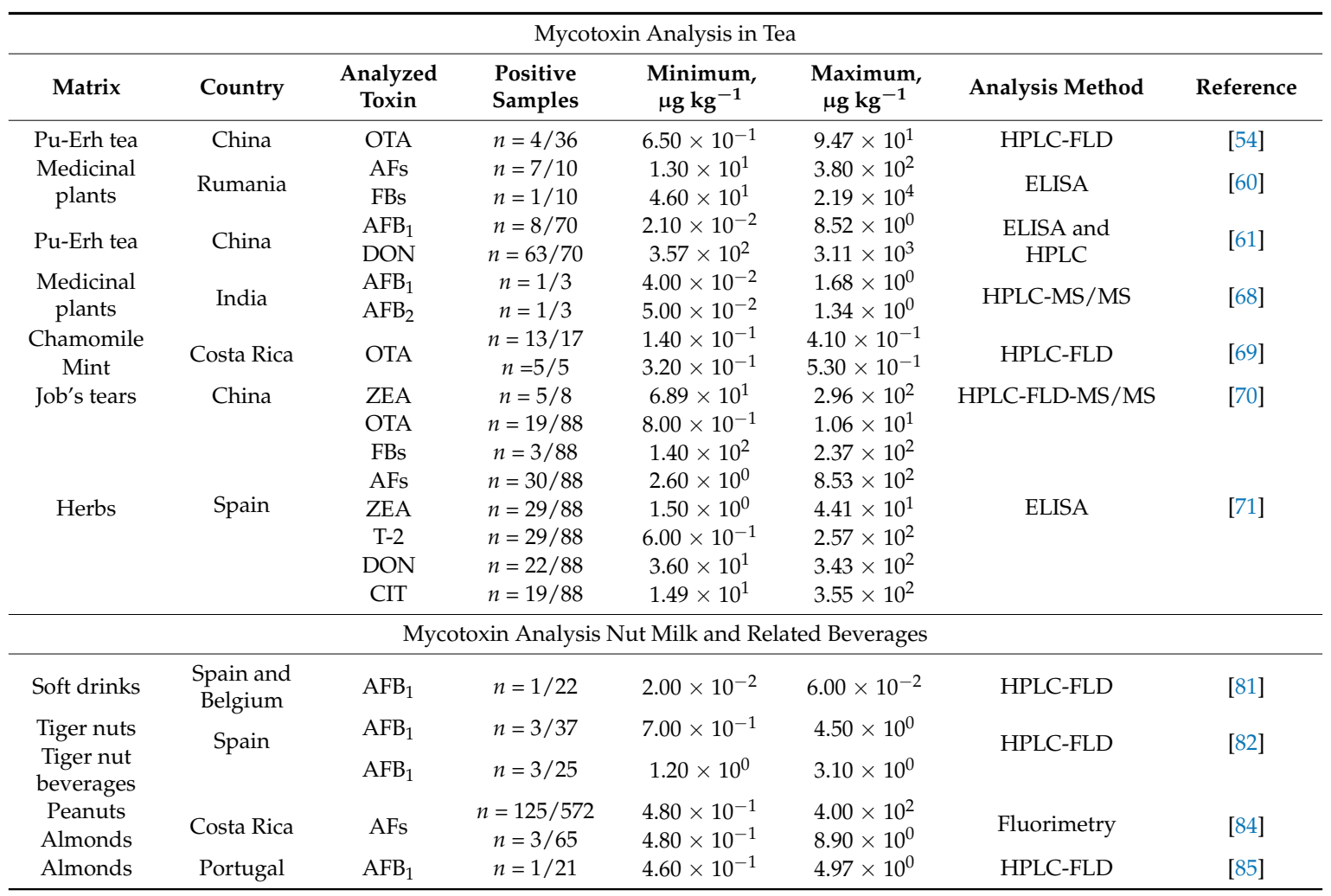


Finally, soy and almond milk are also widely consumed, particularly in vegetarian diets. Even though Latin-American countries (e.g., Brazil, Argentina) are significant exporters of soybean [89], little research has been focused on the resulting concentration of toxins associated with this product. However, considering the nature of the starting material involved, there is a distinct probability of soy and almond milk being a route of exposure for consumers. For example, toxicologically relevant concentrations of OTA were found in every step of soy milk and bean curd processing [90]; however, these toxin levels were decreased compared to the original concentrations found in the soybean [90].

\subsection{Fermented Beverages}

Fermentation of milk, cereals and other substrates is used to produce traditional drinks, especially in regions such as Asia, Africa, Europe, the Middle East and South America [91]. Praised for their health-promoting benefits and functional properties, these drinks have gained popularity, and nowadays biotechnological advances have made it possible to develop them commercially [91]. However, these types of beverages are subject to contamination with mycotoxins, having a deleterious effect on any of the favorable properties mentioned above.

Ezekiel and coworkers gave special attention to traditional African fermented beverages as a source of mycotoxin contamination [18]. A recent example is "Namibian oshikundu", a traditional drink based on sorghum and pearl millet. Misihairabgwi and coworkers found AFs, cyclopiazonic acid, 3-nitropropionic acid, helvolic acid, gliotoxin, fumiquinazolines, cytochalasin E, PAT, FBs, curvularin, alternariol $(\mathrm{AOH})$, dihydroergosine, and tryptoquivalines. Unusually high levels of $2.28 \times 10^{3}$ and $1.19 \times 10^{4} \mathrm{\mu g} \mathrm{kg}^{-1}$ for cyclopiazonic acid and 3-nitropropionic acid were found in sorghum malts, respectively. As with other beverages, fermented beverages such as oshikundu may harbor essential levels of mycotoxin contamination highly related to the quality of the raw ingredients [92].

South American fermented beverages based on cereals and vegetables such as "chichi" (based on corn, grains and fruit including corn beer or "chicha de jora" and the non-alcoholic chicha morada), "caxiri", and "cauim" or "manioc" beer (both based on Manihot esculenta L.), and "champús" (common in Peru, Ecuador and Colombia, mostly based on corn, honey, caramel, whole sugar cane, orange leaves, cloves, pineapple, "naranjilla" or "lulo" Solanum quitoense Lam. and cinnamon) can be cited $[83,93]$. Previously, toxigenic fungi have been described in corn and corn-based foods, feeds and vine fruits in South American countries [94,95]. However, fermented beverages based on lactic acid bacteria metabolism may suffer less from mycotoxin contamination as fungal colonization is considerably more difficult, since these bacteria can produce antimicrobial substances during the malting process $[93,96]$. Degradation of $\mathrm{AFB}_{1}$ has already been described during alcoholic beverage fermentation [97]. In yet another example, fermented apple juice (produced from fruit previously inoculated with Penicillium exapansum) using Saccharomyces cerevisiae exhibited lower PAT concentrations when compared to the unfermented and the pasteurized juices [98].

As mentioned previously, whey, along with extracts from fruits and vegetables, have found widespread use in the manufacture of fermented beverages. Incorporation of these drinks into human diets can be beneficial, as they have good nutritional properties [99]. Fermented beverage manufacturing is practical for adding value to milk whey, a traditionally discarded by-product [99]. These types of beverages usually enjoy a high degree of acceptance due to their low acidity level, creamy consistency, and high commercial value at a relatively low cost [99]. Several tropical and subtropical fruit pulps are used for the production of fermented dairy beverages in Latin America, e.g., guava, soursop (Annona muricata L.), mango, umbu (Spondias tuberosa Arruda), strawberry and peach [99]. More examples of by-product repurposing include beverages prepared with passion fruit [100], i.e., fermented milk, and drinkable yogurts using peel [101-103], and peel and seed flour [104]. Later on, it will be evident that fruits can be a source of mycotoxin contamination which may very well reach final products [6]. Interestingly, allergic sensitization to whey protein has been described after exposure to DON [105]. 


\subsection{Coffee}

Coffee is the second-most consumed beverage worldwide and is prepared by infusion of roasted coffee (mainly Coffea robusta L. Linden, Coffea arabica L. and Coffea liberica W. Bull ex Hiern) seeds. During its cultivation and processing, different fungi can contaminate the beans and berries [15]. Among these fungi, Aspergillus ochraceus, A. carbonarius, A. niger, and Penicillium verrucosum have been described as OTA producers [15,106-108]. OTA has been associated with the Balkan Endemic Nephropathy, a chronic kidney disease, and the development of urinary tract tumors [5]; therefore, it has been classified as a possible carcinogenic compound (group 2B) for humans by the International Agency for Research on Cancer (IARC) [109]. Thus, due to its nephrotoxic, hepatotoxic, teratogenic and immunosuppressive effects [109], this mycotoxin contamination of coffee's raw materials and finished products has been extensively studied (Table 3).

Table 3. The occurrence of OTA in green, roasted and soluble (instant) coffee samples.

\begin{tabular}{|c|c|c|c|c|c|}
\hline \multirow{2}{*}{ Country } & \multirow{2}{*}{$\begin{array}{l}\text { Positive } \\
\text { Samples }\end{array}$} & \multicolumn{2}{|c|}{ OTA Concentration $\left(\mu \mathrm{gg}^{-1}\right)$} & \multirow{2}{*}{ Analysis Method } & \multirow{2}{*}{ Reference } \\
\hline & & Mean & Max & & \\
\hline \multicolumn{6}{|c|}{ Decaffeinated coffee } \\
\hline Spain & $36 / 40^{\mathrm{e}}$ & $4.4 \times 10^{0}$ & 32.40 & LC-MS/MS & [2] \\
\hline \multicolumn{6}{|c|}{ Green coffee beans } \\
\hline Denmark & $7 / 18$ & $1.7 \times 10^{0}$ & $2.8 \times 10^{0}$ & UHPLC-MS/MS & [110] \\
\hline Panamá & $4 / 21^{a}$ & $2.6 \times 10^{1}$ & $3.8 \times 10^{1}$ & ELISA & [111] \\
\hline \multicolumn{6}{|c|}{ Roasted coffee } \\
\hline Spain & $61 / 169$ & $1.9 \times 10^{0}$ & $4.7 \times 10^{0}$ & LC-MS/MS-QqQ-IT & [1] \\
\hline Spain & $7 / 52^{b}$ & $4.1 \times 10^{0}$ & $1.1 \times 10^{1}$ & LC-MS/MS & [2] \\
\hline Chile & $18 / 24$ & $4.7 \times 10^{-1}$ & $8.5 \times 10^{-1}$ & HPLC/fluorescence detector (FLD) & [15] \\
\hline Costa Rica & $54 / 57$ & $3.5 \times 10^{-1}$ & $9.6 \times 10^{-1}$ & ELISA (RIDASCREEN ${ }^{\circledR}$ Ochratoxin A) & [106] \\
\hline Denmark & $26 / 57^{c}$ & $2.3 \times 10^{0}$ & $2.1 \times 10^{1}$ & UHPLC-MS/MS & [110] \\
\hline Brazil & $23 / 34^{d}$ & $9.0 \times 10^{-1}$ & $6.5 \times 10^{0}$ & HPLC/FLD & [111] \\
\hline \multicolumn{6}{|c|}{ Soluble coffee } \\
\hline Italy & $42 / 44$ & $1.3 \times 10^{0}$ & $6.4 \times 10^{0}$ & HPLC/FLD & [5] \\
\hline Chile & $37 / 39$ & $1.8 \times 10^{0}$ & $7.3 \times 10^{0}$ & HPLC/FLD & {$[15]$} \\
\hline Denmark & $14 / 25$ & $4.5 \times 10^{0}$ & $8.3 \times 10^{0}$ & UHPLC-MS/MS & [110] \\
\hline Brazil & $14 / 14$ & $2.2 \times 10^{0}$ & $5.1 \times 10^{0}$ & HPLC/FLD & [112] \\
\hline Portugal & $9 / 10^{\mathrm{f}}$ & $2.8 \times 10^{0}$ & $1.2 \times 10^{1}$ & HPLC/FLD & [113] \\
\hline
\end{tabular}

Santini and coworkers analyzed the effect of preparation methods on the concentration of OTA. They spiked samples of roasted Arabica coffee with 2.00 and $4.00 \times 10^{0} \mu \mathrm{g}$ OTA kg${ }^{-1}$ and determined the OTA concentration of five coffee beverages: American, Moka, Neapolitan, Italian espresso and Turkish coffee. The coffee brewing process that resulted in the lowest amount of OTA was the Neapolitan coffee, with 46.5 and $40.7 \%$, while the American coffee preparation retrieved the most significant amount of the toxin, with 81.0 and $70.0 \%$ at 2.00 and $4.00 \times 10^{0} \mu \mathrm{g}$ OTA kg ${ }^{-1}$, respectively. Differences may be related to a longer contact time between the coffee powder and the hot water during American coffee preparation [107].

The European Community has established maximum regulatory thresholds for OTA in coffee at $5.00 \times 10^{0}$ and $1.00 \times 10^{1} \mathrm{\mu g} \mathrm{kg}^{-1}$ for roasted and soluble coffee, respectively (Regulation EC 1881/2006). Furthermore, in 2007, the Joint Expert Committee on Food Additives (JECFA) set a Provisional Tolerable Weekly Intake (PTWI) of $1.00 \times 10^{-1} \mu \mathrm{g} \mathrm{kg}^{-1}$ bw week ${ }^{-1}$ [114], whereas the European Food Safety Authority (EFSA) Scientific Panel on Contaminants in the Food Chain has established a PTWI of $1.20 \times 10^{-1} \mu \mathrm{g} \mathrm{kg}^{-1} \mathrm{bw}_{\text {week }}^{-1}$ [115]. On the other hand, OTA is not the only mycotoxin present in coffee. García-Moraleja and coworkers developed a method for the simultaneous determination of 21 mycotoxins $\left(\mathrm{OTA}, \mathrm{AFB}_{1}, \mathrm{AFB}_{2}, \mathrm{AFG}_{1}, \mathrm{AFG}_{2}\right.$, sterigmatocystin, 
NIV, DON, 3-acetyldeoxynivalenol (3-aDON), 15-acetyldeoxynivalenol (15-aDON), diacetoxyscirpenol (DAS), NEO, T-2 toxin, HT-2 toxin, $\mathrm{FB}_{1}, \mathrm{FB}_{2}$, enniatin (EN) A, ENA $1, \mathrm{ENB}, \mathrm{ENB}_{1}$ and beauvericin (BEA) in coffee beverages by liquid chromatography-tandem mass spectrometry. They analyzed six coffee samples (three of ground coffee and three of instant coffee), of which five were contaminated with mycotoxins, with the co-occurrence of at least six mycotoxins. OTA was present in two samples: $1.8 \times 10^{0} \mu \mathrm{g} \mathrm{kg}^{-1}$ (ground decaffeinated coffee) and $4.90 \times 10^{0} \mu \mathrm{g} \mathrm{kg}^{-1}$ (instant coffee with sugar and milk added). Only five (15-aDON, DAS, $\mathrm{AFG}_{2}, \mathrm{ENA}$, and $\mathrm{FB}_{2}$ ) out of the 21 mycotoxins analyzed were not detected in any sample [116]. In another study, AFs were present in 53\% $(n=90 / 169)$ of the analyzed coffee samples; however, there are no regulations for AFs in this product. It is worth noting that no sample exceeded $2.00 \times 10^{0} \mu \mathrm{g} \mathrm{AFB}_{1} \mathrm{~kg}^{-1}$, but $15 \%$ had a concentration of total AFs above $5.00 \times 10^{0} \mu \mathrm{g} \mathrm{kg}^{-1}$ due to $\mathrm{AFG}_{2}$ contamination. The mycotoxins that presented the highest levels were ENA and $\mathrm{ENA}_{1}[1]$.

\subsection{Chocolate Beverage}

Cocoa is the raw material from which chocolate is manufactured [42]. Cocoa trees (Theobroma cacao L.) grow best in humid, tropical climates; therefore, cocoa beans are mainly produced in West Africa (68.4\% of world production), Asia and Oceania (account for 17.6\%) and Central and South America (14.0\%) [42,117,118]. Different microorganisms contaminate the cocoa beans from the outer surfaces of pods, workers' hands and tools, plant leaves, collection baskets, insects, and remaining mucilage in equipment [42]. Mishandled or improperly dried fermented beans are susceptible to filamentous fungi contamination [117]. Among the genera reported are: Aspergillus [42,117,119], Fusarium, Geotrichum [42], Mucor, Penicillium [42,114], Rhizopus and Trichoderma [42]. However, fungi not only spoil the cocoa beans, they are also capable of producing mycotoxins (e.g., OTA and AFs) which are thermally tolerant and can withstand the different stages of chocolate production $[119,120]$. For example, Copetti and coworkers isolated Aspergillus flavus, Aspergillus parasiticus and Aspergillus nomius from cocoa beans. These are fungi capable of producing AFs [121]. Regarding mycotoxin presence in cocoa and cocoa-derived goods, the majority of the studies have dealt with OTA and AF contamination (Table 4). It is worth noting that larger amounts of OTA have been detected in the early crop periods, related to the most humid months with the mildest temperatures [122].

Table 4. Mycotoxin contamination found in cocoa and cocoa-derived goods.

\begin{tabular}{|c|c|c|c|c|c|c|}
\hline \multirow{2}{*}{ Country } & \multirow{2}{*}{$\begin{array}{c}\text { Analyzed } \\
\text { Toxin }\end{array}$} & \multirow{2}{*}{$\begin{array}{l}\text { Positive } \\
\text { Samples }\end{array}$} & \multicolumn{2}{|c|}{ Mycotoxin Concentration $(\mu \mathrm{g} / \mathrm{kg})$} & \multirow{2}{*}{$\begin{array}{l}\text { Analysis } \\
\text { Methods }\end{array}$} & \multirow{2}{*}{ References } \\
\hline & & & Mean & Max & & \\
\hline \multicolumn{7}{|c|}{ Cocoa beans } \\
\hline Brazil & OTA & $38 / 54$ & $1,0 \times 10^{0}$ & $>2$ & HPLC/FLD & [122] \\
\hline Brazil & $\mathrm{AFB}_{1}$ & $11 / 85^{a}$ & $1.1 \times 10^{-1}$ & $6.7 \times 10^{0}$ & HPLC/FLD & [121] \\
\hline \multicolumn{7}{|c|}{ Cocoa powder } \\
\hline Italy & OTA & $40 / 40$ & $5.1 \times 10^{-1}$ & $1.82 \times 10^{0}$ & HPLC & [118] \\
\hline Brazil & OTA & $25 / 25$ & $3.9 \times 10^{-1}$ & $9.2 \times 10^{-1}$ & HPLC/FLD & {$[120]$} \\
\hline Canada & OTA & $n=15$ & $1.2 \times 10^{0}$ & $4.7 \times 10^{0}$ & HPLC/FLD & [119] \\
\hline Brazil & $\mathrm{AF}$ & $24 / 25$ & $5.3 \times 10^{-1}$ & $1.7 \times 10^{0}$ & HPLC/FLD & [120] \\
\hline Canada & $\mathrm{AF}$ & $n=15$ & $1.2 \times 10^{0}$ & $3.52 \times 10^{0}$ & HPLC/FLD & [119] \\
\hline \multicolumn{7}{|c|}{ Chocolate } \\
\hline Italy & OTA & $139 / 260$ & $1.4 \times 10^{-1}$ & $7.4 \times 10^{-1}$ & HPLC & [118] \\
\hline Brazil & OTA & $98 / 100$ & $2.0 \times 10^{-1}$ & $8.7 \times 10^{-1}$ & HPLC/FLD & [120] \\
\hline Canada & OTA & $n=30$ & $2.9 \times 10^{-1}$ & $6.5 \times 10^{-1}$ & HPLC/FLD & [119] \\
\hline Brazil & $\mathrm{AF}$ & $73 / 100$ & $3.0 \times 10^{-1}$ & $9.1 \times 10^{-1}$ & HPLC/FLD & [120] \\
\hline Canada & $\mathrm{AF}$ & $n=30$ & $1.9 \times 10^{-1}$ & $9.1 \times 10^{-1}$ & HPLC/FLD & [119] \\
\hline \multicolumn{7}{|c|}{ Baking chocolate } \\
\hline Canada & OTA & $n=9$ & $4.9 \times 10^{-1}$ & $9.1 \times 10^{-1}$ & HPLC/FLD & [119] \\
\hline Canada & $\mathrm{AF}$ & $n=9$ & $2.7 \times 10^{-1}$ & $6.7 \times 10^{-1}$ & HPLC/FLD & [119] \\
\hline
\end{tabular}


Table 4. Cont.

\begin{tabular}{ccccccc}
\hline \multirow{2}{*}{ Country } & $\begin{array}{c}\text { Analyzed } \\
\text { Toxin }\end{array}$ & $\begin{array}{c}\text { Positive } \\
\text { Samples }\end{array}$ & \multicolumn{2}{c}{ Mycotoxin Concentration $(\mu \mathrm{g} / \mathbf{k g})$} & \multirow{2}{*}{$\begin{array}{c}\text { Analysis } \\
\text { Methods }\end{array}$} & References \\
& & Mean & Max & & \\
\hline Canada & OTA & $n=5$ & $4.3 \times 10^{-1}$ & $5.6 \times 10^{-1}$ & HPLC/FLD & {$[119]$} \\
Canada & AF & $n=5$ & $5.1 \times 10^{-1}$ & $7.6 \times 10^{-1}$ & HPLC/FLD & {$[119]$} \\
\hline \multicolumn{7}{c}{ a Sun drying cocoa beans on platforms. }
\end{tabular}

OTA regulation in cocoa and cocoa products has been set according to the Working Document of the Expert Committee on "Agricultural Contaminants" of the European Commission Scientific Committee on Food. Limits have been set as follows: $2 \times 10^{0} \mu \mathrm{g} \mathrm{kg}^{-1}$ for raw material (e.g., cocoa beans, peeled beans, cocoa cake, nibs, and cocoa powder) and $1 \times 10^{0} \mu \mathrm{g} \mathrm{kg}^{-1}$ for consumer's goods (chocolate powder, chocolate, and chocolate beverages) [122]. Finally, exposure to OTA through chocolate ingestion was determined by Brera and coworkers in an Italian population. They concluded that the teenage male group was the highest consumer of cocoa powder $\left(1.48 \times 10^{1} \mathrm{~g}\right.$ per day), and that the highest OTA weekly intake belonged to the infant and children groups, with $2.42 \times 10^{-3}$ and $1.71 \times 10^{-3} \mathrm{\mu g} \mathrm{kg}^{-1} \mathrm{bw}$ week ${ }^{-1}$, respectively [118].

\subsection{Fruits and Fruit Drinks}

Generally speaking, fruit juices are among the most consumed beverages in the world. The popularity of fruit juices is mostly related to their levels of antioxidants, vitamins, and minerals [7]. The nutritious content of fruit juices is also implicated in health benefits such as prevention of cardiovascular disease, diabetes, and cancer [7]. However, the high content of nutrients in juices may represent a disadvantage regarding microbial spoilage, mostly from yeasts and molds. Fruits used as raw material for the production of beverages are also susceptible to fungal decay; the high sugar content and low $\mathrm{pH}$ typically associated with fruits (2.5-5.0) represents an environmental advantage for fungal growth [35]. As is the case for other tropical food products mentioned in this review, fungal growth in fruits may be accompanied by the accumulation of mycotoxins that can be transferred to derived products throughout the entire processing chain. This phenomenon may be important in those cases where poor-quality fruits are used for further processing [35]. Prevalence of mycotoxins such as PAT in apple juice, apple juice-based products, grape juice, and wine has been widely discussed in the literature [123]. Also, there is an extensive body of research describing the fungal growth and mycotoxin accumulation in the apples and grapes themselves [123]. On the other hand, scientific information about the presence of mycotoxins in juices derived from tropical fruits is scarce, and most of the reports are related to the presence of mycotoxigenic fungi in the raw products. Presence of pathogenic fungi and their metabolites in the raw product may give an idea of the potential for fruit juices to function as a source of contamination for consumers.

\subsubsection{Mycotoxin in Pineapple and Pineapple Juice}

Pineapple (Ananas comosus (L.) Merr.) is a tropical plant grown in warm and humid environments. Like many other tropical crops, pineapple is highly susceptible to fungal diseases, with fusariosis being the most severe [124]. The growth of different Fusarium species may be accompanied with varying levels of mycotoxin accumulation in the plant even in the case of asymptomatic infection [125]. Major secondary metabolites produced by Fusarium in pineapple are moniliformin (MON), BEA, FBs, fusaproliferin, FC and FA [124], regarded as mycotoxins with a high risk potential for animals and humans.

Stepien and coworkers [124] studied the diversity of Fusarium species present in samples of pineapple from different tropical countries. In their study, the authors identified ten different Fusarium species contaminating pineapple; most of the isolates originated from Costa Rica and Ecuador, both significant producers in the international market. Fusarium proliferatum was one of the most 
common contaminants, and the species with the highest capacity to produce mycotoxins according to some in vitro experiments. In another study, Gorna and coworkers [125] studied the ability of some F. proliferatum isolates that originated from different crops (including pineapple) to produce fumonisin after exposure to host plant extracts. These authors demonstrated that pineapple extract was one of the most important promoters of fumonisin accumulation in culture media, and this correlated with a higher induction of genes involved in mycotoxin synthesis. Levels of FBs were as high as $3.97 \times 10^{5} \mathrm{\mu g} \mathrm{kg}^{-1}$ in culture media. Pineapple extract also induced fungal biomass growth of some of the tested strains. Mycotoxin contamination of pineapple in the field may increase the risk of disease from juice consumption. In their study, Stepien and coworkers [124] also observed contamination of pineapple juice samples with FBs and MON. Contamination as high as $2.37 \times 10^{4} \mu \mathrm{g} \mathrm{kg}^{-1} \mathrm{of} \mathrm{FBs}$ was found in some of the samples. On the other hand, some mycotoxins may be produced in the pineapple juice itself as some products could be contaminated with ascospores of some mycotoxigenic fungi (Aspergillus, Penicillium, Fusarium, Byssochlamys, and Neosartorya) [126]. Fungal ascospores can be resistant to physical and chemical treatment used during processing of fruit juices; these ascospores may germinate and spoil the final product while accumulating significant levels of dangerous mycotoxins. In an earlier study, Rice and coworkers [127] proved that Byssochalmys fulva could grow and produce PAT in pineapple juice, even though contamination levels $\left(1.42 \times 10^{4} \mu \mathrm{g} \mathrm{kg}^{-1}\right)$ were lower compared with other juice matrices like blueberry and red raspberry. More recently, Zimmerman and coworkers [128] proved that ascospores of Byssochlamys nivea could germinate and grow in pineapple juice at water activity values as low as 0.90 . B. nivea is a type of fungus with the capacity to produce PAT in pineapple juice while growing. As shown by Bevilacqua and coworkers [129], the survivability in pineapple juice of ascospores of mycotoxigenic species such as F. oxysporum can be reduced by the combination of processing treatments like sodium benzoate, citrus extracts, and High-Pressure Processing. Reports about the natural occurrence of mycotoxins in pineapple juice are scarce. In Greece, Mourkas and coworkers [130] reported that a sample of concentrated pineapple juice of unknown origin had low levels of PAT $\left(7.70 \times 10^{0} \mu_{\mathrm{g} \mathrm{kg}}^{-1}\right)$ after analysis with HPLC. Lee and coworkers [131] applied a new methodology to determine the levels of mycotoxins in different types of fruit juices. All the pineapple juice samples analyzed by Lee and coworkers were positive for 5-hydroxymethylfurfural with contamination levels up to $3.40 \times 10^{2} \mu \mathrm{g} \mathrm{kg}^{-1}$; just 1 out of 6 samples was positive for PAT $\left(3.31 \times 10^{1} \mathrm{\mu g} \mathrm{kg}^{-1}\right)$. Other studies have confirmed the absence of PAT [35,132] and OTA [133].

\subsubsection{Citrus Fruit Juices}

Citrus fruits (e.g., oranges, lemons, tangerines) are obtained from plants that grow in tropical and subtropical climates. As citrus fruits are grown in environments with high temperature and increased humidity, contamination with mycotoxigenic molds is not uncommon. Also, as they usually have $\mathrm{pH}$ values lower than 4 , it is expected that most fungi will attack these fruits [7]. Literature reports have established the capacity of mycotoxigenic molds to proliferate and produce mycotoxins in artificially inoculated citrus fruits. In general, oranges seem to support higher levels of mold growth compared with other types of citrus fruits such as lemons, limes, and tangerines. Even though Penicillium digitatum and Penicillium italicum are the most severe infectious pathogens in oranges, other mold species can be observed as well [134,135]. Tournas and Katsoudas [136] demonstrated that several types of mycotoxigenic molds, including Alternaria, Cladosporium, Penicillium, and Fusarium, were able to proliferate in oranges, limes, lemons, and tangerines; higher growth was observed in oranges, with Alternaria being the most common type. In an early study, Alderman and Marth [137] studied the capacity of Aspergillus parasiticus to grow and produce aflatoxins in grapefruit, lemons, limes, and oranges; in this study, it was shown that the mold grew under conditions of low relative humidity (13-20\%), and that it was able to produce aflatoxins up to $2.20 \times 10^{2} \mu \mathrm{g} \mathrm{kg}^{-1}$. Differences were observed with regard to the type of fruit, with lower growth on limes compared with the other products. 
Similarly, Stinson and coworkers [138] demonstrated that different Alternaria isolates were able to grow and produce mycotoxins in artificially inoculated whole oranges and lemons; mycotoxins produced included $\mathrm{AOH}$, alternariol monomethyl ether (AME), and TEA. In oranges, some Alternaria isolates were able to synthesize up to $6.1 \times 10^{4} \mu \mathrm{g} \mathrm{kg}-1$ of TEA and up to $4.1 \times 10^{4} \mu \mathrm{g} \mathrm{kg}^{-1}$ of AOH; mycotoxin production in lemons was significantly lower. Alternaria toxins have been documented as naturally occurring in tangerine [139]. Mold growth is also dependent on the substrate; in the case of grapefruits, mold growth is higher on the peel than in juices, and this may be associated with the concentration of nitrogenous compounds available for fungal metabolism [35].

Some studies have demonstrated the natural presence of mycotoxigenic molds and mycotoxins in citrus fruits and derived juices. Several species of mycotoxigenic molds such as A. flavus, A. niger, F. oxysporium, Fusarium moniliforme, and Penicillium citrinum can be isolated from fresh and rotten oranges [140]. As a consequence, natural presence of mycotoxins in citrus fruits is expected, as contamination with $\mathrm{AOH}, \mathrm{AME}$ and TEA has been reported in oranges, lemons and tangerines $[6,7]$. $\mathrm{AFB}_{1}$ at levels up to $5.20 \times 10^{1} \mu \mathrm{g} \mathrm{kg}{ }^{-1}$ has also been observed in oranges [35]. Presence of AFs and other mycotoxins in citrus fruits is crucial, as they can be carried over to derived products such as purees and juices. Higher levels of contamination can be observed in the peel and pulp, but concentrations as high as $13 \%$ could be transferred to the juices [141]. Fungal contamination may also be transferred from the fruits to the juices and mycotoxins may be produced within the final products themselves. The study of Alderman and Marth [137] also demonstrated that, in grapefruit juice, some strains of $A$. flavus and Aspergillus parasiticus could produce up to $1.20 \times 10^{3} \mu \mathrm{g} \mathrm{kg}^{-1}$ of $\mathrm{AFB}_{1}$ and $1.65 \times 10^{3} \mu \mathrm{g} \mathrm{kg} \mathrm{kg}^{-1} \mathrm{AFB}_{2}$, respectively. In orange juice, $A$. parasiticus was able to produce $5.5 \times 10^{3} \mu \mathrm{g} \mathrm{kg}^{-1}$ of $\mathrm{AFB}_{1}$ after 14 days of incubation at $28^{\circ} \mathrm{C}$. Regardless of the type of juice, the levels of mycotoxins started to decline after prolonged storage.

Similarly, Varma and Verma [142] showed that some toxigenic A. flavus isolates could produce up to $6.5 \times 10^{3} \mu \mathrm{g} \mathrm{kg}$-1 of $\mathrm{AFB}_{1}$ in orange juice after 10 days of incubation at room temperature; these authors also observed a reduction in mycotoxins levels after some time. More recently, Marino and coworkers [143] demonstrated that another Aspergillus species, A. westerdijkiae, was able to grow in oranges and orange juice and produce OTA. After 20 days of incubation at $26^{\circ} \mathrm{C}$, OTA levels in the juice were above $2 \mu \mathrm{g} \mathrm{kg}^{-1}$ and decreased with longer incubation. Natural occurrence of mycotoxins in citrus fruits juices has been reported previously in different parts of the world. For example, in Greece, Mourkas and coworkers [130] reported PAT contamination of three orange juice samples sold in the local market, with an average amount of $6.80 \times 10^{0} \mu \mathrm{g} \mathrm{kg}-1$ of the mycotoxin.

Similarly, Cho and coworkers [144] determined the levels of PAT contamination of various fruit juices sold in South Korea, including orange juice. Even though low levels of prevalence were reported ( 2 out of 24 positive samples), mycotoxin was quantified at concentrations up to $3.09 \times 10^{1} \mu \mathrm{g} \mathrm{kg}^{-1}$, which surpasses the maximum daily recommendation for infants and young children, according to European and Korean authorities. In Argentina, Broggi and coworkers [145] reported positive orange and grapefruit juice samples for Alternaria mycotoxins even though the specific levels of contamination were not established. In China, Zhao and coworkers [146] reported TEA and $\mathrm{AOH}$ in $11.1 \%$ and $25 \%$ of citrus juices (type not specified). Levels of $\mathrm{AOH}$ ranged from $1.21 \times 10^{0}$ to $4.30 \times 10^{0} \mu \mathrm{g} \mathrm{kg}{ }^{-1}$, whereas the TEA was between 0.11 and $2.00 \times 10^{-1} \mu \mathrm{g} \mathrm{kg}^{-1}$. Regarding contamination with OTA, no contamination has been reported in the case of orange juices $[147,148]$.

Mycotoxins in the final juice may present different levels of stability to common processing techniques. It was observed that pasteurization of orange juice can decrease the levels of aflatoxin in orange juice up to $20 \%$ of the single toxin. $\mathrm{AFB}_{1}$ seems to be the most heat resistant mycotoxin [141]. Other control strategies are focused on the growth of pathogenic fungi on oranges, and some of those approaches try to get the advantage of the natural defenses of the citrus plants. For example, some compounds, like the phytoalexins, can be used to inhibit the growth of A. parasiticus and F. verticillioides, as well as the amount of AFs and FBs produced by some isolates in oranges [149]. The process of curing (treatment at $40{ }^{\circ} \mathrm{C}$ and subsequent storage at 5 and $20^{\circ} \mathrm{C}$ for some days) has also been shown 
to effectively control the levels of infection of oranges with Penicillium molds. It is estimated that this process of curing enhances the natural defenses already present in oranges [134]. Green mold sporulation in oranges, mostly from Penicillium species, could be prevented with the use of novel non-thermal approaches like disinfection with ozone. However, the use of ozone seems not to be applicable for fruits packaged in plastic bags and cardboards [150]. Other authors suggest that the best approach is to reduce rates of contamination through in situ monitoring of fungal infections of fruits during storage; this type of monitoring may include direct observation of rotten fruits or earlier detection of fungal metabolites [135].

\subsubsection{Tomato Juice}

Like in the case of citrus fruits, tomato plant (Lycopersicum esculentum) can grow in tropical and subtropical climates. Typically, tomato needs high temperature, high relative humidity, and at least $8 \mathrm{~h}$ of luminosity to develop properly. Many tropical regions offer the ideal climatic conditions for growing tomatoes, but this may increase the risk of contamination with mycotoxigenic molds. As tomatoes have a softer epidermis compared to other fruits, the fungal infestation is common for this product [151]. The soft tissue of tomato also increases the rate of mycotoxin penetration during fungal infection compared with other consistent fruits such as apples and pears [35]. Mycotoxigenic fungi isolated from tomatoes include several species of Penicillium, Alternaria, Aspergillus and Fusarium [151,152]. Hasan determined that Alternaria alternata was the most common fungi isolated from black lesions of rotten tomato followed by A. niger [36]. The pathogenic effect of Alternaria on tomato plants is higher when compared with other cultivars [153]. As Alternaria is the most common mycotoxigenic mold affecting the tomato plant, it is expected that an important fraction of tomatoes and derived products (including juice) will be contaminated with mycotoxins from this genus. Van de Perre and coworkers [151] determined the prevalence of Alternaria mycotoxins in tomatoes from different countries (Belgium, Spain, Brazil, India); levels of contamination were as high as 30 and $18.5 \%$ for $\mathrm{AOH}$ and AME, respectively. Important levels of contamination with TEA were also observed. Interestingly, Van de Perre and coworkers [151] observed lower levels of contamination in tomatoes from tropical regions compared with product from moderate climates. This situation may be attributable to a higher capacity of Alternaria to grow at lower temperatures. Pose and coworkers [154] determined that a temperature of $21^{\circ} \mathrm{C}$ was the optimal condition for the production of $\mathrm{AOH}$ and TEA; this temperature may better reflect a condition of regions with subtropical climates. AOH and AME were also detected in tomato concentrates and tomato puree samples, but no contamination was observed for tomato juices. However, in another study, Ioi [155] reported contamination of tomato juice samples in Canada with $\mathrm{AOH}$ and AME. A lower contamination rate was observed for AME $(17 \%)$ compared to $\mathrm{AOH}$ $(50 \%)$, and the contamination levels were $1.64 \times 10^{1}$ and $2.34 \times 10^{1} \mathrm{\mu g} \mathrm{kg}^{-1}$, respectively. Lopez and coworkers [156] observed that TEA was the most common mycotoxin $(60 \%)$ in tomato-derived products analyzed in the Netherlands. Fourteen tomato juice samples were analyzed in this study, with $50 \%$ of them being positive for TEA (mean level of $7.70 \times 10^{1} \mu \mathrm{g} \mathrm{kg}{ }^{-1}$ ) and $28 \%$ for $\mathrm{AOH}$ (mean level of $3.3 \mu \mathrm{g}$ $\mathrm{kg}^{-1}$ ). No AME was detected in tomato juice samples, even though it was reported from other types of tomato-derived products (sauces, pastes). On the other hand, a study by Zhao and coworkers [146] showed that $100 \%$ of tomato juice samples (9/9) in China were positive for $\mathrm{AOH}$, whereas just $77.8 \%$ of samples had contamination with TEA; levels of contamination were between $7.40 \times 10^{0}-2.78 \times 10^{2}$ and $2.00 \times 10^{-1}-5.8 \times 10^{0} \mu \mathrm{g} \mathrm{kg}{ }^{-1}$ for AOH and TEA, respectively. Higher levels of contamination with TEA are not surprising, as previous in vitro studies [36] demonstrated that some A. alternata isolates could produce between $3.50 \times 10^{1}$ and $6.00 \times 10^{4} \mathrm{\mu g} \mathrm{kg}^{-1}$ of this mycotoxin in solid media. On the other hand, the same isolates produced just a small amount of $\mathrm{AOH}$ in the same experiment (3-7.5 $\times 10^{3} \mathrm{\mu g} \mathrm{kg}^{-1}$ ). Levels of contamination with Alternaria toxins seems to be lower for products made with whole tomato pieces, meaning that for products such as juices, pastes, and sauces, lower-quality raw material may be being used. This tendency was observed by Lopez and coworkers and Zhao and coworkers [146,156]; this latter study found no contamination of Alternaria mycotoxins in fresh tomato, 
whereas derived products (juice, ketchup) were positive for this mycotoxin. As other mycotoxigenic molds different than Alternaria could be found in tomato samples, there is a risk for the presence of more mycotoxins as well. In Egypt, Hegazy [152] observed no contamination of fresh tomato samples with AFs and OTA. Also, Barros Mariutti and Valente Soares [157] studied the presence of AFs in different tomato-based products including ketchup, pulp paste, and puree; no contamination with aflatoxin was found, and even though no tomato juice samples were analyzed, these results may reflect a low risk of contamination for this product. Majerus and coworkers [147] found low levels of OTA in tomato juice samples from Germany but an important level of contamination was found in tomato ketchup. Presence of Alternaria mycotoxins in tomato is a concern, but few studies have focused on the effect of processing on the stability of these compounds. It seems that the use of high temperatures $\left(121^{\circ} \mathrm{C}\right)$ and high pressures $(600 \mathrm{MPa})$ may cause a total reduction of 15.3 and $12.9 \%$ of AME in tomato juice. AME seems to be significantly more stable than $\mathrm{AOH}$. Climate change and the rise of global temperature is another factor to consider, as it may modify the risk for contamination of tomato plants with Alternaria. According to Van de Perre and coworkers [43], the predicted rise in global temperature might decrease the levels of contamination in warmer countries (Spain) compared with more moderate climatic regions (Poland), where the temperature may increase to levels that are optimal for Alternaria growth $\left(14.2-28.4{ }^{\circ} \mathrm{C}\right)$. As was demonstrated in earlier studies [36], optimal temperature conditions for mycotoxin production in Alternaria are between 14 and $28{ }^{\circ} \mathrm{C}$, with a marked decrease at $35^{\circ} \mathrm{C}$. Hypothetically speaking, the increase in climate temperature may reduce the prevalence of Alternaria contamination in tomato from tropical regions, together with the accumulation of mycotoxins; however, more studies will be necessary to confirm this tendency. While fungal synthesis of AOH and TA is reduced at high temperatures, the production of AME may be favored under conditions of high temperature $\left(35^{\circ} \mathrm{C}\right)[154]$.

\subsubsection{Mango Juice}

Mango fruits are juicy stone fruits that comprise several different species of trees from South Asia. Mangifera indica L. is one of the most common varieties in different tropical regions. Even though mango trees can be cultivated in subtropical regions, most of the production comes from regions with warmer temperatures in the tropics [158]. As is the case with other tropical cultivars, mango can be affected with fungal diseases, among which, malformation disease seems to be the most relevant. Malformation disease in mango is mostly caused by Fusarium species, mostly F. filiniforme. The infection of the mango plant may be accompanied by accumulation of mycotoxins like T-2 toxin in the fruit tissue [159]. Some Fusarium isolates associated with mango may produce FBs and MON, as well. As shown by Waffa Haggag and coworkers [160], mango isolates such as F. oxysporum and F. subglutinans can produce $6.30 \times 10^{3}$ and $8.51 \times 10^{3} \mathrm{\mu g} \mathrm{kg}^{-1}$ of MON in liquid media, respectively; lower amounts of FBs are produced by these isolates. However, other fungi may be naturally present in mango as well. Other important species include A. niger, A. flavus and F. oxysporus; all three mycotoxigenic species [158]. Some reports in the literature establish a low level of mango contamination with mycotoxigenic fungi, regardless of symptoms of disease in the fruit [161]. Abdel-Sater and coworkers [162] determined the level of fungal contamination of canned fruit juices marketed in Egypt, including mango juice. The authors confirmed that mango juice samples were contaminated with several species of fungi including some mycotoxigenic varieties such as Aspergillus and Penicillium species; however, no mycotoxin contamination was reported for any of the analyzed samples $(0 / 5)$. Kataoka and coworkers [163] reported no contamination with PAT of mango juice samples marketed in Japan, and this was coincident with the report by Sylos and Rodriguez Amaya [132] in Brazil. Similarly, Filali and coworkers [133] determined that mango juice samples in Morocco were free of OTA contamination. In another study, Anwar and coworkers [164] determined that samples of mango juice in tetra pak containers were contaminated with different fungi with mycotoxigenic potential including A. niger, A. flavus, A parasiticus, and Penicillium. Fungal growth and mycotoxin concentration in mango may be decreased with the use of post-harvest treatments. Chathat and coworkers [165] 
reported that $\gamma$ irradiation $\left(1.5 \mathrm{kGy}\right.$ for $2 \mathrm{~h}$ ), UV light for $1 \mathrm{~h}$, or hot water treatment at $55^{\circ} \mathrm{C}$ could completely reduce the accumulation of aflatoxin in mango fruits. The fungal disease also could be prevented with the use of hot water $\left(50^{\circ} \mathrm{C}\right)$ or exposure to hot air $\left(40^{\circ} \mathrm{C}\right)$ for enough time [166].

\subsubsection{Other Cases}

Many other tropical fruits (banana, papaya, cantaloupe, guava, watermelon) may serve as raw materials for the production of juices. However, as was indicated at the beginning of this section, the available information in the literature about mycotoxin contamination in this type of commodity is scarce. In the case of banana (Musa spp.) fruits, it has been shown that some Fusarium isolates from this product have toxigenic potential. In vitro studies have shown that some isolates can produce important levels of FBs $\left(2.90 \times 10^{6} \mu \mathrm{g} \mathrm{kg}^{-1}\right)$, MON $\left(1.67 \times 10^{6} \mu \mathrm{g} \mathrm{kg}^{-1}\right)$ and ZEA $\left(4.70 \times 10^{5} \mu \mathrm{g} \mathrm{kg}^{-1}\right)$ [167]. On the other hand, $\mathrm{Li}$ and coworker [168] determined that F. oxysporum, which is pathogenic to the banana plant, can produce BEA and FA that are toxic for the plants, and could have effects on human health. As banana is normally used as a complementary ingredient in fruit juices, the possibility of this commodity being an important source of mycotoxin contamination is limited. For guava juice, contamination with aflatoxins up to $1.20 \times 10^{1} \mu \mathrm{g} \mathrm{kg} \mathrm{kg}^{-1}$ has been reported [162], and no PAT contamination was detected in guava (Psidium guajava L.) juice samples analyzed by Sylos and Rodriguez Amaya [131]. Chances of contamination of guava juice from the plant could be important, as this crop can be affected by important fungal pathogens with toxigenic potentials like Fusarium and Alternaria [161]. Some Fusarium isolates from guava fruits can produce FBs to levels up to $1.12 \times 10^{3} \mathrm{\mu g} \mathrm{kg}^{-1}$. Other fruits like melons are also susceptible to fungal diseases from Aspergillus and Penicillium [123]; like in the case of tomato, melons are highly susceptible to fungal infection, as they have high water content and soft tissue [35]. Fusarium and Aspergillus are also common contaminants, causing disease in papaya fruits (Carica papaya) $[169,170]$ that may lead to an accumulation of AFs and other metabolites in the fruit tissue. Other tropical crops such as sugar cane may also serve as sources of mycotoxin exposure for humans. As shown by Abdallah and coworkers [171], $\mathrm{AFB}_{1}$ and $\mathrm{AFG}_{1}$ could be detected in $48 \%$ of sugar cane grass samples and $58 \%$ of sugar cane juice, with a maximum concentration of $3.06 \times 10^{1}$ and $2.10 \times 10^{0} \mu \mathrm{g} \mathrm{kg}$, respectively. $\mathrm{AFG}_{1}$ was also detected in $10 \%$ of grass samples $\left(7.76 \times 10^{0} \mathrm{\mu g} \mathrm{kg}^{-1}\right)$ and $18 \%$ of juice samples. Finally, in an exploratory assay, chili pepper sauces were examined. PAT values varied from $\left(1.8 \times 10^{2} \pm 5.0 \times 10\right)$ to $\left(1.2 \times 10^{3} \pm\right.$ $\left.3.1 \times 10^{2}\right) \mu \mathrm{g} \mathrm{kg}^{-1}$ on dry basis. It is common to find cocktails with pepper sauce as an ingredient. Also, a variety of pepper-derived products, including drinks, are commonly found in other countries where chili pepper consumption is widespread (for example, Mexico). The maximum permitted limits for peppers is currently established at $5.00 \times 10^{1} \mathrm{\mu g} \mathrm{kg}^{-1}[172,173]$.

\section{Methodological Aspects and Approaches for the Determination of Mycotoxins in Selected Matrices}

Mycotoxin analysis and monitoring of both the raw materials from which beverages are made and the drinks themselves (as a final product usually reaching a large number of consumers) are paramount to performing risk analysis and helping industry stakeholders to take actions to reduce such health hazards. It is worth noting that accurate, sensitive, confirmatory and fit-for-purpose methods are available and can be performed in well-equipped and starting laboratories in both developing and high-income countries. Methods that target mycotoxins have been developed to assess multiple analytes in a single run. However, usually, this means that more sophisticated systems are needed and, as a result, are reserved for research and high-end quality-control laboratories. For example, recently, advances in LC/MS techniques to assess several analytes in herbal products (usually used in tea beverage preparation) have been detailed, including a section devoted to mycotoxins [174]. A thorough and specific source for advances in mycotoxin determination in herbs is also available [175]. 


\subsection{Approaches in Sample Preparation}

Wang and coworkers [176] used six different adsorbents (i.e., $\mathrm{C}_{18}$, polymerically bonded secondary amines (PSA), hydrophilic balance (HLB), mixed-mode, strong cation-exchange (MCX), silica, and $\mathrm{NH}_{2}$ ), and assayed 8 different mycotoxins, including $\mathrm{AOH}, \mathrm{AME}$, altenuene (ALT), tentoxin (TEN), TEA, OTA, PAT, and CIT. The combination of MCX and $\mathrm{NH}_{2}$ was found to provide the most effective cleanup, removing the greatest number of matrix interferences and also allowing the quantification of all analyzed mycotoxins in fruits. La Barbera and coworkers used $\mathrm{Fe}_{3} \mathrm{O}_{4}$-graphitized carbon black (mGCB) composites, modified magnetic nanoparticles coated with 3-(trimethoxysilyl)-1-propanthiol, to extract 6 mycotoxins from cereals [177]. Other sample products have been pretreated using this approach (e.g., corn and rice [177], including $\mathrm{AFM}_{1}$ and ZEA (mycoestrogen/F-2 toxin) analysis in milk $[178,179])$. Magnetized carbon nanotubes $[180,181]$ have been used to extract type A TRC in coix seeds [182]. Considering that this is a relatively inexpensive treatment, modified versions of these approaches may very well, in the future, be suited as a food technology to remove toxins from beverages in bulk [183].

\subsection{High-Throughput Multi-Analyte LC-Based Techniques}

\subsubsection{Coupled with MS Detectors}

A significant amount of multi-toxin analysis is increasingly being based on HPLC-MS, HPLC-MS/MS and UPLC-MS/MS [184]. As shown in Table 5, electrospray ionization (ESI) interface is commonly used for mycotoxin analysis. These techniques provide highly sensitive, selective, rapid and reliable quantification and confirmation at the low concentration. For these methods, the most important and critical steps are still sample pretreatment and sample cleanup [185].

Table 5 summarizes the more relevant toxins in beverages and their raw ingredients and approaches used to assess them. Of note, for example, in Spain, García-Moraleja and coworkers developed an assay capable of the simultaneous determination of 21 mycotoxins in coffee beverages [116]. Also, Berthiller and coworkers have already reviewed aflatoxins, Alternaria toxins, ergot alkaloids, FB, OTA, PAT, TRC, and ZEA in botanicals and spices, with particular emphasis on sampling and including newly developed LC-MS-based multi-mycotoxin methods [186]. Nevertheless, regarding these products, a few noteworthy instances are presented herein (Tables 2 and 5). Lately, attention has been devoted to Alternaria toxins [187], with several multitoxin methods considering them during the survey $[188,189]$. On the other hand, derivatization has been used to enhance sensitivity during mycotoxin analysis, even when using MS detection. For example, as TEA is a carbonyl compound, derivatization using 2,4-dinitrophenylhydrazine has been proved to be successful [188]. This approach can also be used to enhance toxin analysis using variable wavelength, a photodiode array or fluorescence detectors.

\subsubsection{Coupled with UV and FLD Detectors}

Though there is a tendency to use tandem MS-based techniques, UV and FLD detector-based LC systems are still widespread in laboratories (see Tables 2-5) which perform routine mycotoxin analysis. As a relevant example, several researchers have used $\mathrm{ZnSO}_{4}$ to detect Alternaria toxins by using UV wavelengths $[189,190]$. An interaction between the keto-enol moiety and the metal ion generate a chelate and, therefore, a structure with an absorption band in the region. 
Table 5. Liquid chromatography-based methodological approaches for the determination of multiple toxins in beverages and raw materials.

\begin{tabular}{|c|c|c|c|c|c|}
\hline Matrix & Target Toxins & Extraction Method & $\begin{array}{c}\text { Column, Detection } \\
\text { Method }\end{array}$ & $\begin{array}{l}\text { Concentrations Found, } \\
\mu \mathrm{gg}^{-1} \text { or } \mu \mathrm{g} \mathrm{L}^{-1} \text { (Total } \\
\text { of Samples Assayed, } n \text { ) }\end{array}$ & Reference \\
\hline \multicolumn{6}{|c|}{ Ochratoxin Determination } \\
\hline Liquorice & OTA & $\begin{array}{l}\text { 80:20 MeOH: } \mathrm{H}_{2} \mathrm{O} \\
\text { NERCB-Solid phase } \\
\text { extraction (SPE) }\end{array}$ & $\begin{array}{c}\text { Xbridge }{ }^{\mathrm{TM}} \mathrm{C}_{18} 150 \times 2.1 \\
\mathrm{~mm}, 3.5 \mu \mathrm{m}, \mathrm{LC}-\mathrm{MS} / \mathrm{MS} \\
\text { QTRAP }^{\circledR}, \mathrm{ESI}^{+}\end{array}$ & $12.99-39.03(26)$ & [191] \\
\hline $\begin{array}{l}\text { Fermented } \\
\text { beverages }\end{array}$ & OTA, T-2 toxin & $\begin{array}{l}\text { 1-octanol, 80:20 } \\
\text { methanol }(\mathrm{MeOH}): \mathrm{H}_{2} \mathrm{O}, \\
\text { hollow fiber liquid phase } \\
\text { microextraction }\end{array}$ & UPLC-MS/MS, ESI ${ }^{+}$ & $<0.02-1.1(9)$ & [192] \\
\hline Malt beverages & OTA & $\begin{array}{l}\text { Dispersive liquid-liquid } \\
\text { acetone } / \mathrm{CHCl}_{3}(73: 27)\end{array}$ & $\begin{array}{c}\text { LC-FLD } \lambda_{\mathrm{ex}} 330 \mathrm{~nm}, \lambda_{\mathrm{em}} \\
460 \mathrm{~nm} \text { Chromolith, } \mathrm{RP}_{18} \\
\text { HPLC column } \\
(100 \times 4.6 \mathrm{~mm})\end{array}$ & $<0.5-4$ (Validation data) & [193] \\
\hline \multicolumn{6}{|c|}{ Alternaria Toxins } \\
\hline $\begin{array}{l}\text { Tomato and tomato } \\
\text { juice }\end{array}$ & $\begin{array}{l}\text { ALT, AOH, TEN, } \\
\text { TEA, AME, and CIT }\end{array}$ & $\begin{array}{l}\text { MeOH, cleanup } \\
\text { Strata-XL SPE cartridges } \\
(200 \mathrm{mg}, 6 \mathrm{~mL}, 100 \mu \mathrm{m})\end{array}$ & $\begin{array}{c}\text { Ascentis Express C-18 } \\
(100 \times 2.1 \mathrm{~mm}, 2.7 \mu \mathrm{m}) \\
\text { TEA derivatized using } \\
\text { 2,4-dinitrophenylhydrazine } \\
\text { TSQ Quantum Ultra triple } \\
\text { quadrupole MS } \\
\text { detector, ESI- }\end{array}$ & 2-50 (Validation data) & [188] \\
\hline $\begin{array}{l}\text { Tomato products } \\
\text { (pulp, paste, } \\
\text { ketchup) }\end{array}$ & $\mathrm{AOH}$ and $\mathrm{AME}$ & $\begin{array}{c}\mathrm{MeOH}, 10 \mathrm{~g} / 100 \mathrm{~mL} \\
\mathrm{NH}_{4} \mathrm{SO}_{4}, \text { liquid-liquid } \\
\text { extraction } \mathrm{CHCl}_{3}\end{array}$ & $\begin{array}{c}\mathrm{C}_{18} 300 \times 2.9 \mathrm{~mm}, 10 \mu \mathrm{m} . \\
300 \mathrm{mg} \mathrm{ZnSO} / \mathrm{L} \text { in mobile } \\
\text { phase. } \mathrm{UV} \text { at } 250 \mathrm{~nm}\end{array}$ & Ketchup: AOH 0.42-1.16 & [189] \\
\hline Peppers & $\mathrm{AOH}, \mathrm{AME}, \mathrm{TEA}$ & $\begin{array}{l}\text { 1. EtOAc, } 1 \mathrm{~mL} / 100 \mathrm{~mL} \\
\mathrm{HCOOH} \text { and } 2 . \\
\text { Liquid-liquid } 20 \mathrm{~g} / 100 \\
\mathrm{~mL} \mathrm{NH}_{4} \mathrm{SO}_{4}, \mathrm{CHCl}_{3} \\
\mathrm{HCl}\end{array}$ & $\begin{array}{l}\text { 1. Kinetex } 100 \times 2.1 \mathrm{~mm} \text {, } \\
2.6 \mu \mathrm{m} \text {. UPLC-DAD/QTOF } \\
\text { mass spectrometer ESI } 2 \text {. } \\
\text { Phenomenex Jupiter } \\
250 \times 4.6 \mathrm{~mm}, 5 \mu \mathrm{m} \mathrm{C}_{18} \text {. } \\
300 \mathrm{mg} \mathrm{ZnSO}_{4} / \mathrm{L} \text { in the } \\
\text { mobile phase. UV } 258 \mathrm{~nm} \\
\text { for AOH and AME, and } \\
280 \mathrm{~nm} \text { for TEA }\end{array}$ & $\begin{array}{l}\text { TEA: 8-11 } 422 \\
\text { AOH: 3-98 } \\
\text { AME: } 7-262\end{array}$ & [190] \\
\hline Tomato & $\mathrm{AOH}, \mathrm{AME}, \mathrm{TEA}$ & $\begin{array}{c}\text { Liquid-liquid extraction } \\
\mathrm{MeOH} / \text { EtOAc }\end{array}$ & $\begin{array}{l}\text { Spherisorb, ODS2 } 250 \times 4.6 \\
\text { mm, } 5.0 \mu \mathrm{m} \text {. UV } 254 \mathrm{~nm}\end{array}$ & $\begin{array}{l}\text { UV absorption match } \\
\text { (Qualitative analysis) }\end{array}$ & [194] \\
\hline $\begin{array}{l}\text { Cereals and cereal } \\
\text { products }\end{array}$ & $\begin{array}{l}\text { AOH, AME, ALT, } \\
\text { TEA, TEN, } \\
\text { altertoxin-I, and } \\
\text { conjugated (sulfates } \\
\text { and glucosides) of } \\
\text { AOH and AME }\end{array}$ & $\begin{array}{c}\text { Acetonitrile } \\
(\mathrm{ACN}) / \mathrm{H}_{2} \mathrm{O} / \mathrm{CH}_{3} \mathrm{COOH} \\
(79 / 19.5 / 1.5) \text {, combined } \\
\text { with a hexane } \\
\text { defatting step }\end{array}$ & $\begin{array}{c}\text { UPLC-ESI }^{ \pm} \text {-MS } / \text { MS } \\
\text { AcquityUPLC HSS T3 } \\
(1.8 \mu \mathrm{m}, 2.1 \mathrm{~mm} \times 100 \mathrm{~mm})\end{array}$ & $\begin{array}{c}\text { Rice: } 71 \%(n=22 / 31), 35 \% \\
(n=11 / 31), 19 \%(6 / 31) \\
\text { contaminated with TEA, } \\
\text { ranges }(1.90 \pm 0.12-113 \pm \\
12), \text { TEN }(3.6 \pm 0.7-15.6 \pm \\
2.9), \text { and AOH }(1.83 \pm \\
0.14-2.97 \pm 0.23) . \text { Oats } \\
\text { flakes: } 31 \%(n=5 / 16) \\
\text { contaminated with TEA } \\
(2.13 \pm 0.18-39 \pm 5)\end{array}$ & [195] \\
\hline \multicolumn{6}{|c|}{ Aflatoxin Determination } \\
\hline Ginger & $\begin{array}{c}\mathrm{AFB}_{1}, \mathrm{AFB}_{2}, \mathrm{AFG}_{1} \\
\mathrm{AFG}_{2}, \mathrm{OTA}\end{array}$ & $\begin{array}{l}\text { Immunoaffinity column, } \\
\mathrm{MeOH}\end{array}$ & $\begin{array}{c}\text { Agilent Poroshell } 120 \\
\text { ECC }_{18} \text { column }(50 \times 4.6 \\
\text { mm, } 2.7 \mu \mathrm{m}) \text { UFLC } 5500 \\
\text { QTRAP }^{\circledR} \text { hybrid triple } \\
\text { quadrupole/near ion trap } \\
\text { mass spectrometer } \\
\text { equipped, } \text { ESI }^{+}\end{array}$ & $\begin{array}{c}<0.25-13.98 \mathrm{AFB}_{1} \\
<0.10-3045.37 \text { OTA } \\
(3 \text { inoculated ginger } \\
\text { powders with A. flavus } \\
\text { and A. carbonarius) }\end{array}$ & [71] \\
\hline Medicinal herbs & $\begin{array}{c}\mathrm{AFB}_{1}, \mathrm{AFB}_{2}, \mathrm{AFG}_{1} \\
\mathrm{AFG}_{2}\end{array}$ & $\begin{array}{c}\text { 70:30 MeOH: } \mathrm{H}_{2} \mathrm{O} \\
\text { Immunoafinity column }\end{array}$ & 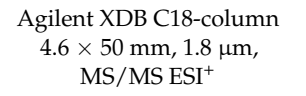 & $<0.14-290.80(174)$ & [196] \\
\hline $\begin{array}{c}\text { Edible and } \\
\text { medicinal herbs }\end{array}$ & $\begin{array}{c}\mathrm{AFB}_{1}, \mathrm{AFB}_{2}, \mathrm{AFG}_{1}, \\
\mathrm{AFG}_{2}, \mathrm{AFM}_{1}, \mathrm{AFM}_{2}, \\
\mathrm{ZEA}, \text { zearalanone, } \\
\alpha / \beta \text {-zeralanol, and } \\
\alpha / \beta \text {-zearalenol }\end{array}$ & $\begin{array}{l}\text { Immunoaffinity column, } \\
N \text {-hydroxysuccinimide- } \\
\text { activated Sepharose } 4 \mathrm{~B} \\
\text { Fast Flow gel with two } \\
\text { group-specific } \\
\text { monoclonal antibodies }\end{array}$ & $\begin{array}{c}\text { Acquity HSS T3 } 2.1 \mathrm{~mm} \times \\
100 \mathrm{~mm} ; 1.8 \mu \mathrm{m} \text { and } \\
\text { Acquity BEH C } 18 \\
2.1 \mathrm{~mm} \times 100 \mathrm{~mm} ; 1.7 \mu \mathrm{m}, \\
\mathrm{MS}^{-\mathrm{MS} \mathrm{ESI}^{ \pm}}\end{array}$ & $\begin{array}{c}\text { AFB1 }<0.03-0.15 \\
\text { AFB2 }<0.03-0.54 \\
\text { ZEA }<0.05-2.78 \\
\text { ZAN }<0.06-10.5 \\
\\
\quad(15)\end{array}$ & [197] \\
\hline
\end{tabular}


Table 5. Cont.

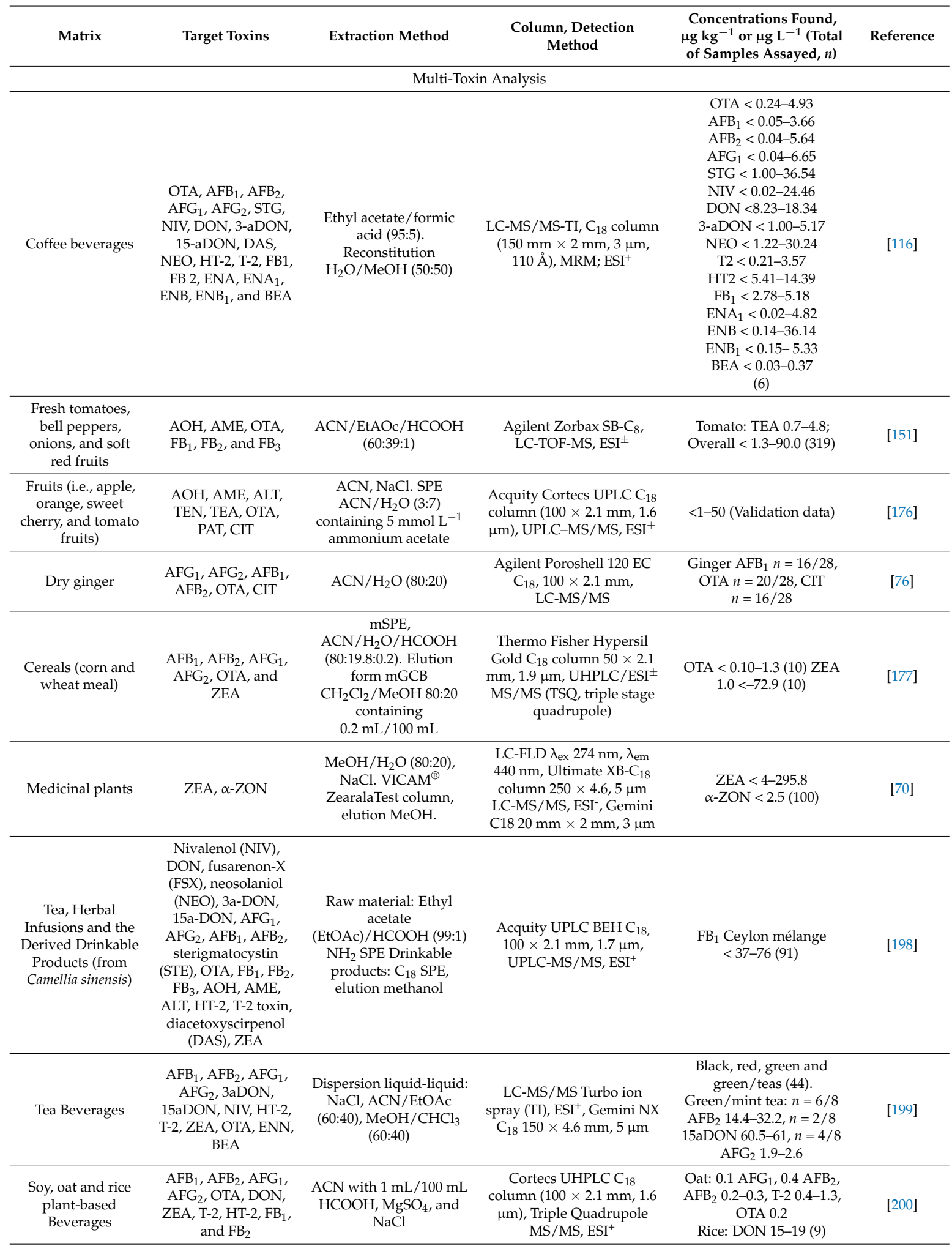


Table 5. Cont.

\begin{tabular}{|c|c|c|c|c|c|}
\hline Matrix & Target Toxins & Extraction Method & $\begin{array}{c}\text { Column, Detection } \\
\text { Method }\end{array}$ & $\begin{array}{l}\text { Concentrations Found, } \\
\mu \mathrm{kg}^{-1} \text { or } \mu \mathrm{g} \mathrm{L}^{-1} \text { (Total } \\
\text { of Samples Assayed, } n \text { ) }\end{array}$ & Reference \\
\hline $\begin{array}{c}\text { Green Coffee Bean } \\
\text { Extracts }\end{array}$ & $\begin{array}{c}\mathrm{OTA}^{\mathrm{O}} \mathrm{OTB}, \mathrm{AFB}_{1}, \\
\mathrm{AFB}_{2}, \mathrm{AFG}_{1}, \mathrm{AFG}_{2} \text {, } \\
\text { TRC A, and } \mathrm{B}, \\
\text { Alternaria toxins, } \mathrm{FB}_{1} \text {, } \\
\mathrm{FB}_{2}, \mathrm{FB}_{3}, \text { enniatins } \\
\left(\text { enniatin } \mathrm{A}, \mathrm{A}_{1}, \mathrm{~B},\right. \\
\left.\mathrm{B}_{1}\right), \mathrm{BEA}, \mathrm{CIT} \text {, } \\
\text { cyclopiazonic, } \\
\text { mycophenolic, and, } \\
\text { PA, penitrem } \mathrm{A}, \\
\text { roquefortine } \mathrm{C}, \\
\text { gliotoxin, } \mathrm{STE} \text {. }\end{array}$ & $\begin{array}{c}\mathrm{H}_{2} \mathrm{O} \text { with } 2 \mathrm{~mL} / 100 \mathrm{~mL} \\
\mathrm{HCOOH} \text { and } \mathrm{ACN} \\
\text { (50:50). } \mathrm{MgSO}_{4}, \mathrm{NaCl} \\
\text { (QuEChERS) }\end{array}$ & $\begin{array}{c}\text { UFLC-QTRAP }{ }^{\circledR} \text { TurboIon } \\
\text { electrospray, ESI and UPLC } \\
\text { quadrupole-orbitrap } \\
\text { HESI-II ESI }\end{array}$ & $\begin{array}{c}\text { OTA, OTB, } \mathrm{FB}_{1} \text { and } \\
\text { mycophenolic acid } \\
\text { prevalence: } 36 \%, 32 \% \text {, } \\
10 \% \text {, and } 16 \% \text {, respectively. } \\
\text { OTA }<1.0-136.9, \text { OTB }< \\
1.0-20.2, \mathrm{FB}_{1}< \\
50.0-415.0, \text { mycophenolic } \\
\text { acid, }<5.0-395.0\end{array}$ & [201] \\
\hline $\begin{array}{l}\text { Berry by-products } \\
\text { Jam/Juice (i.e., } \\
\text { strawberries, } \\
\text { blackberries, } \\
\text { blueberries, } \\
\text { cranberries, and } \\
\text { raspberries) and } \\
\text { mixed in minor } \\
\text { percentage with } \\
\text { grape, } \\
\text { pomegranate, } \\
\text { cherry, apple and } \\
\text { plum juice. }\end{array}$ & $\begin{array}{l}\mathrm{AFB}_{1}, \mathrm{AFB}_{2}, \mathrm{AFG}_{1}, \\
\mathrm{AFG}_{2}, \mathrm{OTA}, \mathrm{AOH}, \\
\mathrm{AME}, \mathrm{TEN}\end{array}$ & $\begin{array}{l}\text { ACN sodium citrate, } \\
\mathrm{MgSO}_{4} \text {, and } \mathrm{NaCl} \\
(\mathrm{QuEChERS})\end{array}$ & $\begin{array}{c}\text { Phenomenex Gemini-NX } \\
\mathrm{C}_{18}(150 \times 2.0 \mathrm{~mm}, 3 \mu \mathrm{m}) \\
\text { LC-MS } / \mathrm{MS} \text { QTRAP }^{\circledR}, \mathrm{ESI}^{+} \\
(\text {Turbo-V } \\
\end{array}$ & $\begin{array}{c}\text { Jams: } 1.6 \mathrm{AFG}_{1} \\
\text { Juices: } 0.9 \mathrm{AFB}_{2} 0.4 \mathrm{AFG}_{1} \text {, } \\
\mathrm{AFG}_{2} 0.7-79, \text { Alternaria } \\
\text { toxins (AOH 2.5-85 and } \\
\mathrm{AME} 267-308) 47 \% \\
\text { prevalence (52) }\end{array}$ & [202] \\
\hline $\begin{array}{l}\text { Evaporated cow } \\
\text { milk }\end{array}$ & $\begin{array}{l}\mathrm{AFM}_{1}, \mathrm{AFB}_{1}, \mathrm{AFB}_{2}, \\
\mathrm{AFG}_{1}, \mathrm{AFG}_{2} ; \mathrm{OTA}, \\
\mathrm{OTB}, \mathrm{FB}_{1}, \mathrm{FB}_{2}, \mathrm{FB}_{3}, \\
\mathrm{HT}-2, \mathrm{~T}-2, \mathrm{NIV}, \mathrm{DON}, \\
\text { deepoxy-DON, } 3 \text { and } \\
\text { 15a-DON, DAS, FSX, } \\
\text { NEO, STE, and ZEA }\end{array}$ & $\begin{array}{c}\text { ACN acidified with } \\
\mathrm{HCOOH}\end{array}$ & $\begin{array}{c}\text { Ascentis Express } \mathrm{C}_{18} \\
\text { column }(150 \times 2.1 \mathrm{~mm}, \\
2.7 \mu \mathrm{m}), \text { Triple Quad }(\mathrm{QqQ}) \\
\text { LC-MS } / \mathrm{MS}\end{array}$ & OTA: $4 / 30<0.2(30)$ & [203] \\
\hline
\end{tabular}

\subsection{Non-Chromatographic Multiple Mycotoxin Analysis}

Constant surveillance of beverages for the presence of mycotoxins would be prudent to reduce risks to human health. Alternative non-chromatographic analytical methods include bioassays and various immunochemical methods, surface plasmon resonance, fluorescence polarization [204], microarray chips, lateral flow [205-207], and nanoparticle-based biosensors [208]. Several new non-chromatographic techniques have been developed to assay mycotoxins in alcoholic beverages (e.g., nanostructured imaging surface plasmon resonance [209], multi-toxin immunoassay [210]), and could be easily implemented to assess contaminants in the matrices mentioned above.

Rapid and on-site screening methods are the first level of screening for food contaminants. Rapid methods have been developed for the detection of such contaminants in foods and beverages. These approaches can be performed by non-specialized personnel, are usually cheap, and some of them can even be applied in situ within fields, plants, and industries (e.g., raw materials, finished product, equipment, work surfaces). Among the rapid methods available, immunochromatographic or lateral flow immunoassay technology has increased scientific and industrial interest in the past few years, and its exploitation has rapidly spread, particularly for mycotoxin detection.

The selection of commercially available tests includes RIDA ${ }^{\circledR}$ QUICK Aflatoxin RQS ECO (AFs in corn), Neogen ${ }^{\circledR}$ Reveal $\mathrm{Q}^{+}$lateral flow (several mycotoxins in grain products) and ProGnosis Biotech, which has an application with an extraction buffer with no organic solvent intervention (Symmetric Total ES Green, AFs in grain products). However, in beverages, these methods have largely been disseminated for alcoholic drink (e.g., wine and grape must [211]), milk [212,213] and cereal analysis [214]. Recent reports have described the use of these techniques to assess Alternaria toxins in fruit [215] and fruit juice [216].

Multiplex lateral flow tests (e.g., $\mathrm{AFB}_{1}, \mathrm{ZEA}$, and $\mathrm{DON}$ ) and biotin/streptavidin-based ELISA $\left(\mathrm{AFB}_{1}, \mathrm{OTA}, \mathrm{ZEA}\right)$ have been developed so that range, versatility, and analyte diversity have been improved [216,217]. The main attraction of these rapid tests is that no laboratory equipment needs 
to be applied. The downside is that sensitivity is usually lacking, and in some cases, one can only assess whether the toxin is present above a certain threshold [218]. Despite any shortcomings, it was calculated that the food and beverage industry invested 95 million USD in these types of tests in 2015 alone [219]. Recently, R-Biopharm ${ }^{\circledR}$ has developed a portable application (RIDA ${ }^{\circledR}$ SMART APP) that can even evaluate the results of a lateral flow assay.

Nowadays, food analysis using microchip is also common [220]. At least one research group has used a microarray immunochip and fluorescence detection to identify OTA in a coffee beverage with a $7 \mu \mathrm{g} \mathrm{kg}^{-1}$ limit of detection [221]. For example, Randox Food Diagnostics has developed a Biochip Array Technology, a multiplex system designed to enable the simultaneous detection of up to 10 of the world's most prevalent mycotoxins. Additionally, an excellent review of biosensor-based methods applied to beverages can be found elsewhere [222]. Aptamer-based technologies are an example of a recent approach [223]. As an example of a novel non-chromatographic analytical method, an aptamer-based technology for the detection of PAT has been described [224]. A comprehensive review of other techniques applied to the mycotoxin analysis in fruits can be found elsewhere [7].

Along the previous sections, we have cited several examples of ELISA applications. Several ELISA kits are commercially available, including Neogen ${ }^{\circledR}$ Veratox ${ }^{\circledR}$ (OTA in green coffee), Astori Tecnic (OTA in coffee, cocoa, cocoa butter), RenekaBio (OTA in coffee, cocoa, and spices), Eurofins Technologies I'screen (OTA in cocoa and green coffee). Even though they are usually considered a screening tool, some ELISA tests can be extremely sensitive. For example, in Iran, non-alcoholic beverages have been evaluated for mycotoxins using ELISA, and higher levels were found in local samples $\left(5.00 \times 10^{-4}-5.54 \times 10^{-1} \mu \mathrm{g} \mathrm{L}^{-1}\right)$ than those that were imported $\left(9.00 \times 10^{-4}-2.29 \times 10^{-1} \mu \mathrm{g} \mathrm{L}^{-1}\right)$ [225]. Most of the immunology-based research for mycotoxin detection is based on the preparation of monoclonal antibodies against the metabolite; these antibodies can be further applied in ELISA techniques and immunoaffinity columns for sample preparation before fluorimetry of HPLC [224]. For example, monoclonal antibodies against OTB were prepared to assay coffee samples [226]. Nanobodies (known as VHH antibodies) have recently been developed for the sole purpose of mycotoxin analysis, as they are easily engineered and have superior stability [227].

\section{Mycotoxin Risk Assessment and Integrated Management Approaches}

\subsection{Masked and Hidden Mycotoxins}

Food is a well-established vehicle for toxin contamination; as such, strategies to estimate mycotoxin exposure must be set [228]. Identification, management, and prevention of emerging food safety risks are paramount as a device for preventing health-threatening incidents [229-231]. The presence of mycotoxins in crops and, more recently, the presence of masked and modified [232,233] mycotoxins, have been considered emerging risks. In this regard, for example, masked and modified forms of fumonisins, $\mathrm{FB}_{1}, \mathrm{FB}_{2}$, and $\mathrm{FB}_{3}$, were assessed to evaluate them as a potential risk for food-producing animals [234].

\subsection{Mycotoxin Risk and Climate Change}

Risk assessment applied to mycotoxins research has demonstrated the need for inclusion of another variable: the effect of climate change [235-238]. As was mentioned previously, some models suggest that increasing temperatures will have a profound effect on Alternaria spp. growth in tomatoes $[239,240]$. As a consequence, $\mathrm{AOH}$ and AME exposure may increase, as more fungi-colonized tomatoes enter the production line (e.g., tomatoes are processed to crop juices). Hence, pre-harvest preventive measures are vital to circumvent mycotoxin contamination. The estimated mean exposure for $\mathrm{AOH}$ and AME were calculated between 0.004 and $0.008 \mu \mathrm{g} \mathrm{kg}^{-1} \mathrm{bw}_{\text {day }}{ }^{-1}$, respectively [239]. Extreme weather conditions can lead to more damage to crops and, hence, more vulnerability to fungi colonization [239]. For example, for groundnut, drought and areas with high humidity favor pre-harvest and post-harvest contamination, respectively [240]. 


\subsection{Multidisciplinary Approaches to Reduce Mycotoxin Contamination}

Food safety issues regarding mycotoxins have been attacked from several perspectives. Pre- and post-harvest prevention practices, decontamination methods [241] and novel physical and chemical approaches for the decontamination of aflatoxin in foods have been recently described [242]. Biological control agents and improved packaging materials have also been considered [243,244]. Genetic transformation, proteomics, RNAi technology, and marker-assisted selection have demonstrated potential in minimizing pre-harvest mycotoxin contamination in crops [245]. Nowadays, plant varietal selection based on the availability of resistant genotypes to fungi could be an option to reduce fungal infestation in cultivars. For example, corn and peanut varietals tolerant to $A$. flavus infection have been described [246,247]. Also, competitive exclusion using non-toxigenic fungal strains has been defined as a routine measure to combat contamination [248]. A GRAS line of attack against mycotoxins for fruits and vegetables (post-harvest) has been suggested [249]. Integrated practices including soil preparation (deep tillage), crop in the rotation and the selection of cultivars have been proposed to control Fusarium head blight and DON in wheat [250]. These approaches, in turn, reduce the risk of exposure to mycotoxins. There is a complex relationship between fungi, the crop, the environment, and mycotoxin generation. Understanding such interactions is indispensable when designing or applying measures for fungal colonization and mycotoxin prevention and control.

\subsection{Mycotoxin Contamination and the Food Chain}

Contamination with pathogens can occur at any point within the production chain, and transdisciplinary approaches are deemed necessary to tackle the issue [251]. Beverage (and raw material) fungal spoilage during processing [252,253] or storage [254] are considered the main causes for production loss [255]. Risk assessment analysis specific to mycotoxins has been documented in grains from developing countries (e.g., corn and peanut, [256,257]) and the most sensitive populations have been considered [258]. Although multidimensional data analysis, harmonization, and interpretation are available for an already-multifaceted issue such as mycotoxins, this issue still represents a challenge for researchers [259]. Good agricultural and manufacturing practices, hazard analysis and critical control points (established within beverage industries) will serve their purpose as long as fungal and mycotoxin contamination analysis (a biological and chemical hazard, respectively) are considered part of quality control [99,260-263]. At least one report has described how to apply a risk management standard directly (i.e., AS/NZS 4360) to the beverage industry [264]. Physical (foreign material, e.g., insect fragments), chemical (water content, total solids, soluble solids, $\mathrm{pH}$ and acidity), microbiological (i.e., mycelial filament count) [190] and biochemical $\left(\mathrm{H}_{2} \mathrm{O}_{2}\right.$ production, cellular damage and death) [194] properties have been described for one fruit that was associated with Alternaria toxins.

\subsection{Selected Health Issues Related to Mycotoxin Exposure}

Mycotoxin risk assessment has, thus far, focused on mutagenic, genotoxic and carcinogenic potential. However, recently, research has integrated gastrointestinal epithelial cell damage into consideration [265]. Significant cellular structural changes and exacerbated immune system activity have been reported after TRC (especially DON) and PAT exposure [265]. Furthermore, chronic intestinal inflammatory diseases and allergic reactions to food, particularly in children and immunocompromised patients, have been linked to mycotoxin exposure [101,266]. As yet another health consequence of mycotoxins, there may be an inherent risk of invasive fungal infections resulting from ingestion or inhalation of food, beverages, or dietary supplements [267]. Vieira and coworkers had previously determined that yerba mate infusion had the potential for carrying potentially pathogenic fungi which were able to survive extreme variations in $\mathrm{pH}$ and temperature, posing a potential health risk [268]. Additionally, case studies for asthma, bronchitis, skin diseases, and other health disorders related to living in moldy humid places have been described [269]. Risk of health effects are increased 
as exposure to multiple toxins is increased; an exposure model has been developed specifically for Latin-American countries [270].

\section{Concluding Remarks and Future Perspectives}

The tropical nations possess a broad diversity of flora and fauna. Throughout the years, many types of vegetable products have been repeatedly exploited for the production of different hot and cold beverages. However, the raw materials from which they are made are prone to fungal contamination and the resulting mycotoxin accumulation. Many tropical countries that provide raw material for beverages are developing economies, where the conditions for cultivation and processing may not be adequate. Also, there may be limited resources to regulate the presence of mycotoxins in some cultivars or to provide appropriate analytical techniques for monitoring levels of contamination. Within the context of a globalized economy, this situation represents a threat to consumers at both the local and global levels; this is evident from the consumption patterns established above. The major consumption trend of beverages made from tropical crops is driven by countries that are not the producers of these cultivars. This means that collaborative efforts should be made between regulatory and scientific organizations of different countries in order to invest in high-quality research to understand the dynamics of mycotoxin contamination for tropical products.

Mycotoxigenic fungi and their metabolites are frequently present in tropical cultivars and their derived products, including different types of beverages (industrial and traditional). According to this review, there seems not to be a specific tendency in terms of lower or higher risk related with some specific products. It seems that all the products reviewed in this document are prone to fungal contamination, and that the most important differences are basically the type of mycotoxins that are present. Even though in some cases there is an extensive body of literature regarding levels of contamination (coffee, tomato), this does not mean that for other products the risk is lower; this is just a reminder that more scientific research is necessary to properly characterize that risk. However, one conclusion that can be made is that products like juices or other beverages may harbor important levels of mycotoxin contamination as they may be processed from low quality raw material. The level of exposure from such products could be significant taking into consideration that some beverages are produced in high quantities using (in some instances) raw material from different sources.

Aspects that are necessary to scientifically address mycotoxin contamination in beverages and their raw materials include the study of the type of fungal contamination of tropical products (with special attention to other genus different than Aspergillus and Penicillium) and the factors affecting it (with special attention to the role of aerial contamination in tropical environments), the fate of mycotoxins during manufacturing of beverages, and the levels of contamination in the beverages already available for consumers; the latter is strictly necessary to establish a baseline for future work. This information could be combined with more recent consumption data, clinical studies related with the pathogenic potential of these toxins and the biology of each fungus to assist in the risk characterization process. For example, metagenomic studies of soil and plant fungal populations could also be conducted to understand mycotoxin production and its role in nature. In terms of methodological approaches, it is clear that various options are suitable for the analysis of mycotoxins in the products described in this review; this is an advantage, as some of them could be considered as inexpensive approaches that could be applied in countries with limited financial resources. This is true in terms of lower cost for some of the techniques (rapid tests, ELISA) or the possibility to adapt one single approach for the analysis of multiple mycotoxins in multiple matrices (MS detectors). However, scientific studies are necessary to validate the application of these methodologies to different beverages.

Considering that beverage production is a manufacturing process that involves several steps of complex food chains, the industry should invest in risk management programs for their crops, as contaminated raw material or finalized products may hinder international trade as a result of strict regulation in high-value markets. Additionally, within the beverage industry, constant surveillance programs should be implemented, especially for the monitoring of raw materials, e.g., dry herbs (i.e., 
aromatic and medicinal plants), coffee cherries, cocoa beans (fruits and fresh/dried seeds), nuts and fresh fruits and pulps. Such surveillance should be performed by versatile, specific, sensible and accurate methods, taking into consideration the most common contaminants present in such matrices, but also considering emerging contaminants (e.g., Fusarium and Alternaria toxins).

Finally, even though mycotoxins are a Public Health issue, since they can be hepatotoxic, nephrotoxic, neurotoxic and teratogenic, there is a lack of international and local legislation that establishes maximum permitted levels of these compounds in tropical commodities.

Author Contributions: All authors contributed equally to this work.

Funding: This research received no external funding.

Acknowledgments: Graciela Artavia is acknowledged for her help with the prints for the plant diagraming, which were the basis for Figure 1. Marelyn Rojas Lezama is recognized for her help doing the experiments regarding PAT in peppers, and Jessie Usaga for providing the samples.

Conflicts of Interest: The authors declare no conflict of interest.

\section{References}

1. García-Moraleja, A.; Font, G.; Mañes, J.; Ferrer, E. Analysis of mycotoxins in coffee and risk assessment in Spanish adolescents and adults. Food Chem. Toxicol. 2015, 86, 225-233.

2. García-Moraleja, A.; Font, G.; Mañes, J.; Ferrer, E. Simultaneous determination of mycotoxin in commercial coffee. Food Control 2015, 57, 282-292. [CrossRef]

3. Ismaiel, A.A.; Papenbrock, J. Mycotoxins: Producing fungi and mechanisms of phytotoxicity. Agriculture 2015, 5, 492-537. [CrossRef]

4. Bennett, J.W.; Klich, M. Mycotoxins. Clin. Microbiol. Rev. 2003, 16, 497-516. [CrossRef] [PubMed]

5. Vecchio, A.; Mineo, V.; Planeta, D. Ochratoxin A in instant coffee in Italy. Food Control 2012, 28, $220-223$. [CrossRef]

6. Fernández-Cruz, M.L.; Mansilla, M.L.; Tadeo, J.L. Mycotoxins in fruits and their processed products: Analysis, occurrence and health implications. J. Adv. Res. 2010, 1, 113-122. [CrossRef]

7. Mandappa, I.M.; Basavaraj, K.; Manonmani, H.K. Analysis of Mycotoxins in Fruit Juices. In Fruit Juices Extraction, Composition, Quality and Analysis; Rajauria, G., Tiwari, B.K., Eds.; Academic Press: Massachusetts, MA, USA, 2018; pp. 763-777. ISBN 978-0-12-802230-6.

8. Chen, W.; Li, C.; Zhang, B.; Zhou, Z.; Shen, Y.; Liao, X.; Yanj, J.; Wang, Y.; Li, Y.; Shen, X.L. Advances in biodetoxification of ochratoxin A-A review of the past five decades. Front. Microbiol. 2018, 9, 1386. [CrossRef] [PubMed]

9. Ji, C.; Fan, Y.; Zhao, L. Review on biological degradation of mycotoxins. Anim. Nutr. 2016, 2, 127-133. [CrossRef] [PubMed]

10. Zain, M.E. Impact of mycotoxins on humans and animals. J. Saudi Chem. Soc. 2011, 15, 129-144. [CrossRef]

11. Iheshiulor, O.O.M.; Esonu, B.O.; Chuwuka, O.K.; Omede, A.A.; Okoli, I.C.; Ogbuewu, I.P. Effects of mycotoxins in animal nutrition: A review. Asian J. Anim. Sci. 2011, 5, 19-33. [CrossRef]

12. Antonissen, G.; Martel, A.; Pasmans, F.; Ducatelle, R.; Verbrugghe, E.; Vandenbroucke, V.; Li, S.; Haesebrouck, F.; Van Immerseel, F.; Croubels, S. The impact of Fusarium mycotoxins on human and animal host susceptibility to infectious diseases. Toxins 2014, 28, 430-452. [CrossRef] [PubMed]

13. Bezerra da Rocha, M.E.; Freire, F.D.C.O.; Maia, F.E.F.; Guedes, M.I.F.; Rondina, D. Mycotoxins and their effects on human and animal health. Food Control 2014, 36, 159-165. [CrossRef]

14. Bui-Klimke, T.; Wu, F. Evaluating weight of evidence in the mystery of Balkan endemic nephropathy. Risk Anal. 2014, 3, 1688-1705. [CrossRef] [PubMed]

15. Galarce-Bustos, O.; Alvarado, M.; Vega, M.; Aranda, M. Occurrence of ochratoxin A in roasted and instant coffees in Chilean market. Food Control 2014, 46, 102-107. [CrossRef]

16. Alshannaq, A.; Yu, J.-H. Occurrence, toxicity, and analysis of major mycotoxins in food. Int. J. Environ. Res. Public Health 2017, 14, 632. [CrossRef] [PubMed]

17. Pal, M. Are mycotoxins silent killers of humans and animals? J. Exp. Food Chem. 2017, 3, e110. [CrossRef]

18. Ezekiel, C.N.; Ayeni, K.I.; Misihariabgwi, J.M.; Somorin, Y.M.; Chibuzor-Onyema, I.E.; Oyedele, O.A.; Abia, W.A.; Sulyok, M.; Shephard, G.S.; Krska, R. Traditionally processed beverages in Africa: A review 
of the mycotoxin occurrence patterns and exposure assessment. Compr. Rev. Food Sci. Food Saf. 2018, 17, 334-351. [CrossRef]

19. Aswani, Y.V.V.; Renuka, R.M.; Bodaiah, B.; Mangamu, U.K.; Vijaya, L.M.; Poda, S. Mycotoxin strategies: Impact on global health and wealth. Pharm. Anal. Acta 2016, 7, 498.

20. Mitchell, N.J.; Bowers, E.; Hurburgh, C.; Wu, F. Potential economic losses to the USA corn industry from aflatoxin contamination. Food Addit. Contam. Part A 2016, 33, 540-550. [CrossRef] [PubMed]

21. Rico-Sole, R. Economic impact of mycotoxins in nuts and dried fruit chain. Acta Hort. 2012, 963, $155-172$. [CrossRef]

22. Kouadio, J.H.; Lattazio, V.M.T.; Ouattara, D.; Kouakou, B.; Visconti, A. Assessment of mycotoxin exposure in Côte d'ivoire (Ivory Coast) through multi-biomarker analysis and possible correlation with food consumption patterns. Toxins 2014, 21, 248-257. [CrossRef] [PubMed]

23. Grigg, D. The worlds of tea and coffee: Patterns of consumption. GeoJournal 2002, 57, 283-294. [CrossRef]

24. Rezaee, E.; Mirlohi, M.; Hassanzadeh, A.; Fallah, A. Factors affecting tea consumption pattern in an urban society in Isfahan, Iran. J. Educ. Health Promot. 2016, 5, 13. [PubMed]

25. Food and Agriculture Organization of the United Nations (FAO); Intergovernmental Group on Tea. Intersessional Meeting. Report of the Working Group on Global Tea Market Analysis and Promotion. 2017. Available online: http:/ / www.fao.org/fileadmin/templates/est/COMM_MARKETS_MONITORING/Tea/ Intersessional_2017/ISM-17-3-GlobalMktAnalysis_Promotion.docx (accessed on 19 September 2018).

26. Instituto del Café de Costa Rica (ICAFE). Informe sobre la Actividad Cafetalera de Costa Rica. Preparado en el Instituto del Café de Costa Rica para los Delegados al XLVI Congreso Nacional Cafetalero Ordinario. 2017. Available online: http:/ / www.icafe.cr/wp-content/uploads/informacion_mercado/informes_actividad/ actual/InformeActividadCafetalera.pdf.pdf (accessed on 21 September 2018).

27. Maurage, P.; Heeren, A.; Pesenti, M. Does chocolate consumption really boost Nobel award chances? The peril of over-interpreting correlations in health studies. J. Nutr. 2013, 143, 931-933. [CrossRef] [PubMed]

28. Noble, M.D. Chocolate and the consumption of forests: A cross-national examination of ecologically unequal exchange in cocoa exports. J. World Syst. Res. 2017, 23, 236-268. [CrossRef]

29. Katz, D.L.; Doughty, K.; Ali, A. Cocoa and chocolate in human health and disease. Antioxid. Redox Signal. 2011, 15, 2779-2811. [CrossRef] [PubMed]

30. Food and Agriculture Organization of the United Nations (FAO). Medium-Term Prospects for Raw Materials, Horticulture and Tropical Products; FAO: Rome, Italy, 2016; pp. 3-26. ISBN 978-92-5-109202-6.

31. Duffey, K.J.; Popkin, B.M. Shifts in patterns and consumption of beverages between 1965 and 2002. Obesity 2007, 15, 2739-2747. [CrossRef] [PubMed]

32. Ng, S.W.; Ostrowski, J.D.; Li, K.-P. Trends in added sugars from packaged beverages available and purchased by US households, 2007-2012. Am. J. Clin. Nutr. 2017, 106, 179-188. [CrossRef] [PubMed]

33. Neves, M.F.; Trombin, V.G.; Lopes, F.F.; Kalaki, R.; Milan, P. World consumption of fruit juices, nectars, and still drinks. In The Orange Juice Business: A Brazilian Perspective; Neves, M.F., Trombin, V.G., Eds.; Wageningen Academic Publishers: Wageningen, The Netherlands, 2011; p. 119. ISBN 978-90-8686-739-4.

34. Reinhardt, A.; Rodríguez, L.V. Industrial processing of pineapple-Trends and perspectives. Acta Hortic. 2009, 822, 323-328. [CrossRef]

35. Drusch, S.; Ragab, W. Mycotoxins in fruits, fruit juices, and dried fruits. J. Food Prot. 2003, 66, $1514-1527$. [CrossRef] [PubMed]

36. Hasan, H.A.H. Patulin and aflatoxin in brown rot lesions of apple fruits and their regulation. World J. Microbiol. Biotechnol. 2000, 16, 607-612. [CrossRef]

37. Karlovsky, P.; Suman, M.; Berthiller, F.; De Meester, J.; Eisenbrand, G.; Perrin, I.; Oswald, I.P.; Speijers, G.; Chiodini, A.; Recker, T.; et al. Impact of food processing and detoxification treatments on mycotoxin contamination. Mycotoxin Res. 2016, 32, 179-205. [CrossRef] [PubMed]

38. Manda, P.; Dano, D.S.; Kouadio, J.H.; Diakite, A.; Sangare-Tigori, B.; Ezoulin, M.J.M.; Soumahoro, A.; Dembele, A.; Fourny, G. Impact of industrial treatments on ochratoxin A content in artificially contaminated cocoa beans. Food Addit. Contam. A 2009, 26, 1081-1088. [CrossRef] [PubMed]

39. Hao, H.; Zhou, T.; Koutchma, T.; Wu, F.; Warriner, K. High hydrostatic pressure assisted degradation of patulin in fruit and vegetable juice blends. Food Control 2016, 62, 237-242. [CrossRef]

40. Christ, D.; Savi, G.D.; Scussel, V.M. Effectiveness of ozone gas application methods against combined multi-contaminants in food. Food Public Health 2017, 7, 51-58. 
41. Ghanem, I.; Orfi, M.; Shamma, M. Effect of gamma radiation on the inactivation of aflatoxin B1 in food and feed crops. Braz. J. Microbiol. 2008, 39, 787-791. [CrossRef] [PubMed]

42. Copetti, M.V.; Iamanaka, B.T.; Pitt, J.I.; Taniwaki, M.H. Fungi and mycotoxins in cocoa: From farm to chocolate. Int. J. Food Microbiol. 2014, 178, 13-20. [CrossRef] [PubMed]

43. Van de Perre, E.; Jacxsens, L.; Liu, C.; Devlieghere, F.; De Meulenaer, B. Climate impact on Alternaria moulds and their mycotoxins in fresh produce: The case of the tomato chain. Food Res. Int. 2015, 68, 41-46. [CrossRef]

44. Laitila, A. Toxigenic fungi and mycotoxins in the barley-to-beer chain. In Brewing Microbiology Managing Microbes, Ensuring Quality and Valorising Waste; Hill, A., Ed.; Elsevier Academic Press: Amsterdam, The Netherlands, 2015; pp. 107-139. ISBN 978-1-78242-331-7.

45. Himery, N.; Vasseur, V.; Coton, M.; Mournier, J.; Jany, J.-L.; Barbier, G.; Coton, E. Filamentous fungi and mycotoxins in cheese: A review. Compr. Rev. Food Sci. Food Saf. 2014, 13, 437-456. [CrossRef]

46. Garnier, L.; Valence, F.; Mournier, J. Diversity and control of spoilage fungi in dairy products: An update. Microorganism 2017, 5, 42. [CrossRef] [PubMed]

47. Comisión Económica para América Latina y el Caribe (CEPAL). Perspectivas de la Agricultura y del Desarrollo Rural en las Américas: Una Mirada Hacia América Latina y el Caribe 2015-2016; Organización de las Naciones Unidas para la Agricultura y la Alimentación (FAO): Rome, Italy; Instituto Interamericano de Cooperación para la Agricultura (IICA): San José, Costa Rica, 2016; pp. 63-88. ISBN 978-92-9248-577-1.

48. Rodríguez, D.I.; Anríquez, G.; Riveros, J.L. Food security and livestock: The case of Latin America and the Caribbean. Cienc. Investig. Agrar. 2016, 43, 5-15. [CrossRef]

49. Chavan, R.S.; Shraddha, R.C.; Kumar, A.; Nalawade, T. Whey based beverage: Its functionality, formulations, health benefits and applications. J. Food Process. Technol. 2015, 6, 1.

50. Pereira, C.; Henriques, M.; Gomes, D.; Gomez-Zavaglia, A.; de Antoni, G. Novel functional whey-based drinks with great potential in the dairy industry. Food Technol. Biotechnol. 2015, 53, 307-314. [CrossRef] [PubMed]

51. Farah, J.S.; Araujo, C.B.; Melo, L. Analysis of yoghurts', whey-based beverages' and fermented milks' labels and differences on their sensory profiles and acceptance. Int. Dairy J. 2017, 68, 17-22. [CrossRef]

52. Patel, R. Technology for Carbonated Lemon Whey Beverage. Res. Rev. J. Food Dairy Technol. 2017, 5, 30-37.

53. Janiaski, D.R.; Pimentel, T.C.; Cruz, A.G.; Prudencio, S.H. Strawberry-flavored yogurts and whey beverages: What is the sensory profile of the ideal product? J. Dairy Sci. 2016, 99, 1-11. [CrossRef] [PubMed]

54. Haas, D.; Pfeifer, B.; Reiterich, C.; Partenheimer, R.; Reck, B.; Buzina, W. Identification and quantification of fungi and mycotoxins from Pu-erh tea. Int. J. Food Microbiol. 2013, 166, 316-322. [CrossRef] [PubMed]

55. Santos, L.; Marín, S.; Sanchis, V.; Ramos, A.J. Mycotoxin in medicinal/aromatic herbs-A review. Boletín Latinoamericano y del Caribe de Plantas Medicinales y Aromáticas 2013, 12, 119-142.

56. Chang, K. World Tea Production and Trade: Current and Future Development; FAO: Rome, Italy, 2015; pp. 1-13.

57. Hilal, M.I.M.; Mubarak, K.M. International tea marketing and need for reviving Sri Lankan tea industry. J. Manag. 2013, 9, 25-38. [CrossRef]

58. Zhao, J.; Ge, L.Y.; Xiong, W.; Leong, F.; Huang, L.Q.; Li, S.P. Advanced development in phytochemicals analysis of medicine and food dual purposes plants used in China (2011-2014). J. Chromatogr. A 2016, 1428, 39-54. [CrossRef] [PubMed]

59. Trucksess, M.W.; Scott, P.M. Mycotoxins in botanicals and dried fruits: A review. Food Addit. Contam. Part A 2008, 25, 181-192. [CrossRef] [PubMed]

60. Matei, S.; Szakacs, A.; Macri, A. Medicinal plants used for tea, mycological and mycotoxicological potential. Bull. UASVM Vet. Med. 2015, 72, 352-356. [CrossRef]

61. Wu, J.-Y.; Yang, G.-Y.; Chen, J.-L.; Li, W.-X.; Li, J.-T.; Fu, C.-X.; Jiang, G.-F.; Zhu, W. Investigation for Pu-Erh tea contamination caused by mycotoxins in a tea market in Guangzhou. J. Basic Appl. Sci. 2014, 10, 349-356.

62. Ning, J.; Sun, J.; Li, S.; Sheng, M.; Zhang, Z. Classification of five Chinese tea categories with different fermentation degrees using visible and near infrared hyperspectral imaging. Int. J. Food Prop. 2017, 20, 1515-1520. [CrossRef]

63. Li, Q.; Huang, J.; Li, Y.; Zhang, Y.; Luo, Y.; Chen, Y.; Lin, H.; Wang, K.; Liu, Z. Fungal community succession and major components change during manufacturing process of Fu brick tea. Sci. Rep. 2017, 7, 6947. [CrossRef] [PubMed] 
64. Li, Q.; Chai, S.; Li, Y.; Huang, J.; Luo, Y.; Xiao, L.; Liu, Z. Biochemical components associated with microbial community shift during the pile-fermentation of primary dark tea. Front. Microbiol. 2018, 9, 1509. [CrossRef] [PubMed]

65. Khanongnuch, C.; Unban, K.; Kanpiengjai, A.; Saenjum, C. Recent research advances and ethno-botanical history of miang, a traditional fermented tea (Camellia sinensis var. assamica) of northern Thailand. J. Ethn. Foods 2017, 4, 135-144. [CrossRef]

66. Han, T.; Aye, K.N. The legend of laphet: A Myanmar fermented tea leaf. J. Ethn. Foods 2015, 2, $173-178$. [CrossRef]

67. Horie, M.; Nara, K.; Sugino, S.; Umeno, A.; Yoshida, Y. Comparison of antioxidant activities among four kinds of Japanese traditional fermented tea. Feed Sci. Nutr. 2017, 5, 639-645. [CrossRef] [PubMed]

68. Siddique, N.A.; Mujeeb, M.; Ahmad, S.; Panda, B.P.; Makhmoor, M. Determination of aflatoxins in medicinal plants by high-performance liquid chromatography-tandem mass spectrometry. J. Pharm. Pharm. Sci. 2013, 16, 321-330. [CrossRef] [PubMed]

69. Blanco, J.; Araya, E.B.; Granados-Chinchilla, F.; Gutiérrez, A.L. Evaluation of the quality of natural products for the preparation of chamomile and mint tea in Costa Rica. World J. Pharmacol. Res. 2017, 6523, 44-55.

70. Kong, W.-J.; Shen, H.-H.; Zhang, X.-F.; Yang, X.-L.; Qiu, F.; Ou-yang, Z.; Yang, M.-H. Analysis of zearalenone and $\alpha$-zearalenol in 100 foods and medicinal plants determined by HPLC-FLD and positive confirmation by LC-MS-MS. J. Sci. Food Agric. 2013, 93, 1584-1590. [CrossRef] [PubMed]

71. Santos, L.; Marín, S.; Sanchis, V.; Ramos, A.J. Screening of mycotoxin multicontamination in medicinal and aromatic herbs sampled in Spain. J. Sci. Food Agric. 2009, 89, 1802-1807. [CrossRef]

72. Malir, F.; Ostry, V.; Pfohl-Leszkowicz, A.; Toman, J.; Bazin, I.; Roubal, T. Transfer of ochratoxin A into tea and coffee beverages. Toxins 2014, 6, 3438-3453. [CrossRef] [PubMed]

73. Nian, Y.; Wang, H.; Ying, G.; Yang, M.; Wang, Z.; Kong, W.; Yang, S. Transfer rates of aflatoxins from herbal medicines to decoctions determined by an optimized high-performance liquid chromatography with fluorescence detection method. J. Pharm. Pharmacol. 2018, 70, 278-288. [CrossRef] [PubMed]

74. Alvarenga, A.A.A.; López, I.P.P.; Abraham, C.M.R.; Caballero, Y.M.R.; Popoff, C.T.; Vázquez, L.; Arrua, J.M.M. Presencia de hongos filamentosos en yerba mate compuesta y eficiencia de medios de cultivo para el aislamiento de Aspergillus. Investig. Agrar. 2016, 18, 49-55. [CrossRef]

75. Castrillo, M.L.; Jerke, G.; Horianksi, M.A. Detección de la producción de ocratoxina A por cepas de Aspergillus sección Nigri aisladas de yerba mate compuesta. Rev. Mex. Micol. 2014, 40, 1-6.

76. Yang, Z.; Wang, H.; Ying, G.; Yang, M.; Nian, Y.; Liu, J.; Kong, W. Relationship of mycotoxins accumulation and bioactive components variation in ginger after fungal inoculation. Front. Pharmacol. 2017, 8, 331. [CrossRef] [PubMed]

77. Jaswal, P.; Kumar, D. Mycobiota and natural incidence of aflatoxins, ochratoxin A, and citrinin in Indian spices confirmed by LC-MS/MS. Int. J. Microbiol. 2015, 2015, 242486. [CrossRef] [PubMed]

78. Kalaiselvi, P.; Rajashree, K.; Priya, L.B.; Padma, V.V. Cytoprotective effect of epigallocatechin-3-gallate against deoxynivalenol-induced toxicity through anti-oxidative and anti-inflammatory mechanisms in HT-29 cells. Food Chem. Toxicol. 2013, 56, 110-118. [CrossRef] [PubMed]

79. Sugiyama, K.-I.; Kinoshita, M.; Kamata, Y.; Minai, Y.; Sugita-Konishi, Y. (-)-Epigallocatechin gallate suppresses the cytotoxicity induced by trichothecene mycotoxins in mouse cultural macrophages. Mycotoxin Res. 2011, 27, 281-285. [CrossRef] [PubMed]

80. Sánchez-Zapata, E.; Fernández-López, J.; Pérez-Álvarez, J.A. Tiger nut (Cyperus esculentus) commercialization: Health aspects, composition, properties, and food applications. Compr. Rev. Food Sci. Food Saf. 2012, 11, 366-377. [CrossRef]

81. Arranz, I.; Stroka, J.; Neugebauer, M. Determination of aflatoxin $\mathrm{B}_{1}$ in tiger nut-based soft drinks. Food Addit. Contam. Part A 2006, 23, 305-308. [CrossRef] [PubMed]

82. Sebastià, N.; Soler, C.; Soriano, J.M.; Mañes, J. Occurrence of aflatoxins in tigernuts and their beverages commercialized in Spain. J. Agric. Food Chem. 2010, 58, 2609-2612. [CrossRef] [PubMed]

83. Rueda, J.; Jimenez, E.; Lobo, M.; Sammán, N. Andean Fermented Beverages. In Fermented Foods of Latin America from Traditional Knowledge to Innovative Applications; Barretto Penna, A.L., Nero, L.A., Todorov, S.D., Eds.; CRC Press/Taylor \& Francis Group, LLC: Boca Raton, FL, USA, 2017; ISBN 978-1-4987-3811-8. 
84. Granados-Chinchilla, F.; Molina, A.; Chavarría, G.; Alfaro-Cascante, M.; Bogantes-Ledezma, D.; Murillo-Williams, A. Aflatoxins occurrence through the food chain in Costa Rica: Applying the One Health approach to mycotoxin surveillance. Food Control 2017, 82, 217-226. [CrossRef]

85. Rodrigues, P.; Venâncio, A.; Lima, N. Mycobiota and mycotoxins of almonds and chestnuts with special reference to aflatoxins. Food Res. Int. 2012, 45, 76-90. [CrossRef]

86. Rodrigues, P.; Venâncio, A.; Lima, N. Aflatoxigenic fungi and aflatoxins in Portuguese almonds. Sci. World J. 2012, 2012, 471926. [CrossRef] [PubMed]

87. Lamboni, Y.; Nielsen, K.F.; Linnemann, A.R.; Gezgin, Y.; Hell, K.; Nout, M.J.R.; Smid, E.J.; Tamo, M.; van Boekel, M.A.J.S.; Hoof, J.B.; et al. Diversity in secondary metabolites including mycotoxins from strains of Aspergillus Section Nigri isolated from raw cashew nuts from Benin, West Africa. PLoS ONE 2016, 11, e0164310. [CrossRef] [PubMed]

88. Valle Garcia, M.; Mallmann, C.A.; Copetti, M.V. Aflatoxigenic, and ochratoxigenic fungi and their mycotoxins in spices marketed in Brazil. Food Res. Int. 2018, 106, 136-140. [CrossRef] [PubMed]

89. Beherens, A. Soy-Based Beverages in Latin America. In Multinationals in Latin America: Case Studies; Liberman, L., Garcilazo, S., Stal, E., Eds.; Macmillan Distribution Ltd.: Hampshire, UK, 2014; pp. 113-120. ISBN 978-1-349-66879-3.

90. Iha, M.H.; Trucksess, M.W.; Rader, J.I. The fate of ochratoxin A in soy milk and bean curd (tofu) productions. In Mycotoxin Prevention and Control in Agriculture; Appell, M., Kendra, D.F., Trucksess, M.W., Eds.; American Chemical Society: Washington, DC, USA, 2010; pp. 59-68. ISBN 978-084-12-6990-3.

91. Marsh, A.J.; Hill, C.; Ross, R.P.; Cotter, P.D. Fermented beverages with health-promoting potential: Past and future perspectives. Trends Food Sci. Technol. 2014, 38, 113-124. [CrossRef]

92. Misihairabgwi, J.M.; Ishola, A.; Quaye, I.; Sulyok, M.; Krska, R. Diversity and fate of fungal metabolites during the preparation of oshikundu, a Namibian traditional fermented beverage. World Mycotoxin J. 2018, 11, 471-481. [CrossRef]

93. Faria-Oliveira, F.; Diniz, R.H.S.; Godoy-Santos, F.; Piló, F.B.; Mezadri, H.; Castro, I.M.; Brandão, R.L. The Role of Yeast and Lactic Acid Bacteria in the Production of Fermented Beverages in South America. In Food Production and Industry; Eisa, A.A., Ed.; IntechOpen Limited: London, UK, 2015; pp. 107-135. ISBN 978-953-51-2191-6.

94. Magnoli, C.E.; Astoreca, A.L.; Chiacchiera, S.M.; Dalcero, A.M. Occurrence of ochratoxin A and ochratoxigenic mycoflora in corn and corn based foods and feeds in some South American countries. Mycopathologia 2007, 163, 249-260. [CrossRef] [PubMed]

95. Romero, S.M.; Comerio, R.M.; Larumbe, G.; Ritieni, A.; Vaamonde, G.; Fernández Pinto, V. Toxigenic fungi isolated from dried vine fruits in Argentina. Int. J. Food Microbiol. 2005, 104, 43-49. [CrossRef] [PubMed]

96. Lowe, D.P.; Arendt, E.K. The use and effects of lactic acid bacteria in malting and brewing with their relationships to antifungal activity, mycotoxins and gushing: A review. J. Inst. Brew. 2004, 110, 163-180. [CrossRef]

97. Inoue, T.; Nagatomi, Y.; Uyama, A.; Mochizuki, N. Degradation of aflatoxin $B_{1}$ during the fermentation of alcoholic beverages. Toxins 2013, 5, 1219-1229. [CrossRef] [PubMed]

98. Håkansson, O. Reducing Patulin Levels in Apple Juice by Fermentation with Saccharomyces cerevisiae; G2E; Sveriges Lantbruksuniversitet (SLU): Uppsala, Sweden, 2015.

99. Casarotti, S.N.; Diamantino, V.R.; Silva, L.F.; Afonso dos Santos, C.L.; Toedoro de Paula, A.; Barretto Penna, A.L. Fermented Dairy Beverages in Latin America. In Fermented Foods of Latin America from Traditional Knowledge to Innovative Applications; Barretto Penna, A.L., Nero, L.A., Todorov, S.D., Eds.; CRC Press/Taylor \& Francis Group, LLC: Boca Raton, FL, USA, 2017; ISBN 978-1-4987-3811-8.

100. Coelho, E.M.; Gomes, R.G.; Souza Machado, B.A.; Santos Oliveira, R.; dos Santos Lima, M.; Cavalcanti de Acevedo, L.; Umsza Guez, M.A. Passion fruit peel flour-Technological properties and application in food products. Food Hydrocoll. 2017, 62, 158-164. [CrossRef]

101. Célia, J.A.; Pereira da Silva, M.A.; Borges de Oliveira, K.; Freitas e Souza, J.L.; Souza, D.G.; Campos de Moura, L.; Marins da Silva, R.; Cagnin, C.; Morais de Freitas, B.S.; Rocha Plácido, G.; et al. Fermented milk enriched with passion fruit peel flour (Passiflora edulis): Physicochemical and sensory aspects and lactic acid bacteria viability. Afr. J. Microbiol. Res. 2015, 9, 1964-1973.

102. Vieira, N.F.; Silva, M.A.P.; Martins, Y.A.A.; Souza, D.G.; Lima, M.S.; Plácido, G.R.; Caliari, M. Physicochemical and sensory profile of yogurt added with passion fruit peel flour. Afr. J. Microbiol. Res. 2015, 14, 149-155. 
103. Silva, C.E.F.; Abud, A.K.S. Tropical fruit pulps: Processing, product standardization and main control parameters for quality assurance. Braz. Arch. Biol. Technol. 2017, 60, e160209. [CrossRef]

104. Viva de Toledo, N.M.; Costa de Camargo, A.; Mendes Ramos, P.B.; Button, D.C.; Granato, D.; Canniatti-Brazaca, S.G. Potentials and pitfalls on the use of passion fruit by-products in drinkable yogurt: Physicochemical, technological, microbiological, and sensory aspects. Beverages 2018, 4, 47. [CrossRef]

105. Bol-Schoenmakers, M.; Braber, S.; Akbari, P.; de Graaff, P.; van Roest, M.; Kruijssen, L.; Smit, J.J.; van Esch, B.C.; Jeurink, P.V.; Garssen, J.; et al. The mycotoxin deoxynivalenol facilitates allergic sensitization to whey in mice. Mucosal Immunol. 2016, 9, 1477-1486. [CrossRef] [PubMed]

106. Quintana-Guzmán, E.M.; Antillón-Guerrero, F.; Azofeifa-Chaves, J. Determinación de ocratoxina A en plasma humano y en café de Costa Rica por un método de ELISA. Arch. Latinoam. Nutr. 2007, 57, 168-172.

107. Santini, A.; Ferracane, R.; Mikušová, P.; Eged, Š.; Šrobárová, A.; Meca, G.; Mañes, J.; Ritieni, A. Influence of different coffee drink preparations on ochratoxin A content and evaluation of the antioxidant activity and caffeine variations. Food Control 2011, 22, 1240-1245. [CrossRef]

108. Mitchell, N.J.; Chen, C.; Palumbo, J.D.; Bianchini, A.; Cappozzo, J.; Stratton, J.; Ryu, D.; Wu, F. A risk assessment of dietary Ochratoxin a in the United States. Food Chem Toxicol. 2017, 100, 265-273. [CrossRef] [PubMed]

109. International Agency for Research on Cancer Possibly carcinogenic to humans. Monogr. Eval. Carcinog. Risks Hum. 1993, 56, 245-395.

110. Nielsen, K.F.; Ngemela, A.F.; Jensen, L.B.; de Medeiros, L.S.; Rasmussen, P.H. UHPLC-MS/MS determination of ochratoxin A and fumonisins in coffee using QuEChERS extraction combined with mixed-Mode SPE purification. J. Agric. Food Chem. 2015, 63, 1029-1034. [CrossRef] [PubMed]

111. Franco, H.; Vega, A.; Reyes, S.; de León, J.; Bonilla, A. Niveles de Ocratoxina A y Aflatoxinas totales en cafés de exportación de Panamá por un método de ELISA. Arch. Latinoam. Nutr. 2014, 64, 42-49.

112. Leoni, L.A.; Soares, L.M.; Oliveira, P.L. Ochratoxin A in Brazilian roasted and instant coffees. Food Addit. Contam. 2000, 17, 867-870. [CrossRef] [PubMed]

113. Casal, S.; Vieira, T.; Cruz, R.; Cunha, S.C. Ochratoxin A in commercial soluble coffee and coffee substitutes. Food Res. Int. 2014, 61, 56-60. [CrossRef]

114. Joint FAO/WHO Expert Committee on Food Additives (JECFA). Evaluation of Certain Food Additives and Contaminants: 68th Report of the Joint FAO/WHO Expert Committee on Food Additives; WHO: Geneva, Switzerland, 2007.

115. European Food Safety Authority (EFSA). Opinion of the Scientific Panel on Contaminants in the Food Chain on a request from the Commission related to ochratoxin A in food. EFSA J. 2006, 4, 356.

116. García-Moraleja, A.; Font, G.; Mañes, J.; Ferrer, E. Development of a new method for the simultaneous determination of 21 mycotoxins in coffee beverages by liquid chromatography tandem mass spectrometry. Food Res. Int. 2015, 72, 247-255. [CrossRef]

117. Sánchez-Hervás, M.; Gil, J.V.; Bisbal, F.; Ramón, D.; Martínez-Culebras, P.V. Mycobiota and mycotoxin producing fungi from cocoa beans. Int. J. Food Microbiol. 2008, 125, 336-340. [CrossRef] [PubMed]

118. Brera, C.; Debegnach, F.; de Santis, B.; Iafrate, E.; Pannunxi, E.; Berdini, C.; Prantera, E.; Gregori, E.; Miraglia, M. Ochratoxin A in cocoa and chocolate products from the Italian market: Occurrence and exposure assessment. Food Control 2011, 22, 1663-1667. [CrossRef]

119. Turcotte, A.M.; Scott, P.M.; Tague, B. Analysis of cocoa products for ochratoxin A and aflatoxins. Mycotoxin Res. 2013, 29, 193-201. [CrossRef] [PubMed]

120. Copetti, M.V.; Iamanaka, B.T.; Pereira, J.L.; Lemes, D.P.; Nakano, F.; Taniwaki, M.H. Co-occurrence of ochratoxin A and aflatoxins in chocolate marketed in Brazil. Food Control 2012, 26, 36-41. [CrossRef]

121. Copetti, M.V.; Iamanaka, B.T.; Pereira, J.L.; Fungaro, M.H.; Taniwaki, M.H. Aflatoxigenic fungi and aflatoxin in cocoa. Int. J. Food Microbiol. 2011, 148, 141-144. [CrossRef] [PubMed]

122. De Magalhães, J.T.; Sodré, G.A.; Viscogliosi, H.; Grenier-Loustalot, M. Occurrence of Ochratoxin A in Brazilian cocoa beans. Food Control 2011, 22, 744-748. [CrossRef]

123. Barkai-Golan, R. Chapter 7: Penicillium Mycotoxins. In Mycotoxins in Fruits and Vegetables; Barkai-Golan, R., Paster, N., Eds.; Elsevier: Berkeley, CA, USA, 2008; pp. 153-185.

124. Stepién, L.; Koczyk, G.; Waskiewicz, A. Diversity of Fusarium species and mycotoxins contaminating pineapple. J. Appl. Genet. 2013, 54, 367-380. 
125. Górna, K.; Pawlowicz, I.; Waskiewicz, A.; Stepién, L. Fusarium proliferatum strains change fumonisin biosynthesis and accumulation when exposed to host plant extracts. Fungal Biol. 2016, 120, 884-893. [CrossRef] [PubMed]

126. Faten; Mansour, S.; Nagy, K.S.; Taqi, A.; Abass, K. Factors affecting the fungal contamination of some fruit juices packaged in Tetra Pack. Afr. J. Biotechnol. 2011, 10, 12957-12962.

127. Rice, S.L.; Beuchat, R.L.; Worthington, R.E. Patulin production by Byssochlamys spp. in fruit juices. Appl. Environ. Microbiol. 1977, 34, 791-796. [PubMed]

128. Zimmerman, M.; Miorelli, S.; Massaguer, P.R.; Aragao, G.M.F. Growth of Byssochlamys nivea in pineapple juice under the effect of water activity and ascospore age. Braz. J. Microbiol. 2011, 42, 203-210. [CrossRef] [PubMed]

129. Bevilacqua, A.; Campaniello, D.; Sinigaglia, M.; Ciccarone, C.; Corbo, M.R. Sodium-benzoate and citrus extract increase the effect of homogenization towards spores of Fusarium oxysporum in pineapple juice. Food Control 2012, 28, 199-2014. [CrossRef]

130. Mourkas, A.; Panagiotopoulou, V.; Markaki, P. Determination of patulin in fruit juices using HPLC-DAD and GC-MSD techniques. Food Chem. 2008, 109, 860-867. [CrossRef] [PubMed]

131. Lee, T.P.; Sakai, R.; Abdul Manaf, N.; Mohd Rodhi, A.; Saad, B. High performance liquid chromatography method for the determination of patulin and 5-hydroxymethylfurfural in fruit juices marketed in Malaysia. Food Control 2014, 38, 142-149. [CrossRef]

132. De Sylos, C.M.; Rodriguez-Amaya, D.B. Incidence of patulin in fruits and fruit juices marketed in Campinas, Brazil. Food Addit. Contam. 1999, 2, 71-74. [CrossRef] [PubMed]

133. Filali, A.; Ouammi, L.; Betbeder, A.M.; Baudrimont, I.; Soulaymani, R.; Benayada, A.; Creppy, E.E. Ochratoxin A in beverages from Morocco: A preliminary survey. Food Addit. Contam. 2001, 6, 565-568. [CrossRef] [PubMed]

134. Nunes, C.; Usall, J.; Manso, T.; Torres, R.; Olmo, M.; García, J.M. Effect of High Temperature Treatments on Growth of Penicillium spp. and their Development on 'Valencia' Oranges C. Food Sci. Technol. Int. 2007, 13, 63-68. [CrossRef]

135. Pallottino, F.; Costa, C.; Antonucci, F.; Strano, M.C.; Calandra, M.; Solainia, S.; Menesattia, P. Electronic nose application for determination of Penicillium digitatum in Valencia oranges. J. Sci. Food Agric. 2012, 92, 2008-2012. [CrossRef] [PubMed]

136. Tournas, V.H.; Katsoudas, E. Mould and yeast flora in fresh berries, grapes and citrus fruits. Int. J. Food Microbiol. 2005, 105, 11-17. [CrossRef] [PubMed]

137. Alderman, G.G.; Marth, E.H. Experimental production of aflatoxin on intact citrus fruit. J. Milk Food. Technol. 1974, 37, 451-456. [CrossRef]

138. Stinson, E.E.; Osman, S.F.; Heisler, E.G.; Siciliano, J.; Bills, D.D. Mycotoxin production in whole tomatoes, apples, oranges, and lemons. J. Agric. Food Chem. 1981, 29, 790-792. [CrossRef] [PubMed]

139. Scott, P.; Kanhere, S. Stability of Alternaria toxins in fruit juices and wine. Mycotoxin Res. 2001, 17, 9-14. [CrossRef] [PubMed]

140. Adegoke, G.O.; Ojo, O.A.; Odelade, K.A. Survey of the post harvest diseases and aflatoxin contamination of marketed orange fruit (Citrus sp.) in major cities in Oyo State, Nigeria. J. Agric. Vet. Sci. 2014, 7, 27-31.

141. Ragab, W.S.; Rashwan, M.A.; Saleim, M.A. Natural occurrence and experimental proliferation of aflatoxins on orange fruits. J. Agric. Sci. Mansoura Univ. 1999, 9, 4885-4893.

142. Varma, S.K.; Verma, R.A.B. Aflatoxin B1 production in orange (Citrus reticulata) juice by isolates of Aspergillus flavus Link. Mycopathologia 1987, 97, 101-104. [CrossRef] [PubMed]

143. Marino, A.; Nostro, A.; Fiorentino, C. Ochratoxin A production by Aspergillus westerdijkiae in orange fruit and juice. Int. J. Food Microbiol. 2009, 132, 185-189. [CrossRef] [PubMed]

144. Cho, M.S.; Kim, K.; Seo, E.; Kassim, N.; Mtenga, A.B.; Shim, W.B.; Lee, S.H.; Chung, D.H. Occurrence of patulin in various fruit juices from South Korea: An exposure assessment. Food Sci. Biotechnol. 2010, 19, 1-5. [CrossRef]

145. Broggi, L.; Reynoso, C.; Resnik, S.; Martinez, F.; Drunday, V.; Romero Bernal, A. Occurrence of alternariol and alternariol monomethyl ether in beverages from the Entre Rios Province market, Argentina. Mycotoxin Res. 2013, 29, 17-22. [CrossRef] [PubMed]

146. Zhao, K.; Shao, B.; Yang, D.; Li, F. Natural occurrence of four Alternaria mycotoxins in tomato- and citrus-based foods in China. J. Agric. Food Chem. 2015, 63, 343-348. [CrossRef] [PubMed] 
147. Majerus, P.; Bresch, H.; Ottender, H. Ochratoxin A in wines, fruit juices and seasonings. Arch. Lebensmittelhyg. 2000, 51, 95-97.

148. Zimmerli, B.; Dick, R. Ochratoxin A in table wine and grape-juice: Occurrence and risk assessment. Food Addit. Contam. 1996, 13, 655-668. [CrossRef] [PubMed]

149. Mohanlall, V.; Odhav, B. Biocontrol of Aflatoxins B1, B2, G1, G2, and Fumonisin B1 with 6,7-Dimethoxycoumarin, a Phytoalexin from Citrus sinensis. J. Food Prot. 2006, 69, 2224-2229. [CrossRef] [PubMed]

150. Palou, L.; Smilanickb, J.L.; Crisostoa, C.H.; Mansourb, M.; Plaza, P. Ozone gas penetration and control of the sporulation of Penicillium digitatum and Penicillium italicum within commercial packages of oranges during cold storage. Crop Prot. 2003, 22, 1131-1134. [CrossRef]

151. Van de Perre, E.; Deschuyffeleer, N.; Jacxsens, L.; Vekeman, F.; Van Der Hauwaert, W.; Asam, S.; Rychlik, M.; Devlieghere, F.; De Meulenaer, B. Screening of moulds and mycotoxins in tomatoes, bell peppers, onions, soft red fruits and derived tomato products. Food Control 2014, 37, 165-170. [CrossRef]

152. Hegazy, E.M. Mycotoxin and fungal contamination of fresh and dried tomato. Annu. Res. Rev. Biol. 2017, 17, 1-9. [CrossRef]

153. Meena, M.; Swapnil, P.; Upadhyay, R.S. Isolation, characterization and toxicological potential of Alternaria-mycotoxins (TeA, AOH and AME) in different Alternaria species from various regions of India. Sci. Rep. 2017, 7, 8777. [CrossRef] [PubMed]

154. Pose, G.; Patriarca, A.; Kyanko, V.; Pardo, A.; Fernández Pinto, V. Water activity and temperature effects on mycotoxin production by Alternaria alternata on a synthetic tomato medium. Int. J. Food Microbiol. 2010, 142, 348-353. [CrossRef] [PubMed]

155. Ioi, D.J. Occurrence of Alternariol and Alternariol Monomethyl Ether in Apple and Tomato Products and Resistance to Food Processing. Master's Thesis, University of Guelph, Guelph, ON, Canada, 2017.

156. Lopez, P.; Venema, D.; Mol, H.; Spanjer, M.; de Stoppelaar, J.; Pfeiffer, E.; de Nijs, M. Alternaria toxins and conjugates in selected foods in the Netherlands. Food Control 2016, 69, 153-159. [CrossRef]

157. Barros Mariutti, L.R.; Valente Soares, L.M. Survey of aflatoxins in tomato products. Food Sci. Technol. 2009, 29, 431-434. [CrossRef]

158. Chatha, Z.A.; Anjum, F.M.; Zahoor, T. Comparative effects of postharvest mitigation treatments on mycotoxins production potential of Aspergillus parasiticus in mango (Mangifera indica L.) fruit. Pak. J. Phytopathol. 2014, 26, 97-101.

159. Marasas, W.F.O.; Ploetz, R.C.; Wingfield, M.J.; Wingfield, B.D.; Steenkamp, E.T. Mango malformation disease and the associated fusarium species. Phypatology 2006, 6, 667-672.

160. Wafaa Haggag, M.; Hazza, M.; Sehab, A.; Abd El-Wahab, M. Mango Malformation: I. Toxin Production Associated with Fusarium Pathogens. Am. J. Plant Sci. 2011, 2, 276-281.

161. Ammar, M.I.; El-Naggar, M.A. Screening and characterization of fungi and their associated mycotoxins in some fruit crops. Int. J. Adv. Res. 2014, 2, 1216-1227.

162. Abdel-Sater, M.A.; Zohri, A.A.; Ismail, M.A. Natural contamination of some Egyptian fruit juices and beverages by mycoflora and mycotoxins. J. Food Sci. Technol. 2001, 398, 407-411.

163. Kataoka, H.; Itano, M.; Ishizaki, A.; Saito, K. Determination of patulin in fruit juice and dried fruit samples by in-tube solid-phase microextraction coupled with liquid chromatography-mass spectrometry. J. Chromatogr. A 2009, 1216, 3746-3750. [CrossRef] [PubMed]

164. Anwar, A.; Perween, R.; Nazim, K.; Shaukat, S.S.; Mehmood, T.; Qamar-Ul-Haque. Assessment of physico-chemical properties and fungal contamination in plastic bottles and tetra packed mango juices marketed in Karachi city. Int. J. Biol. Biotechnol. 2013, 10, 411-416.

165. Chatha, Z.A.; Ahmad, A.; Zahoor, T.; Raza, A.; Kaleem, M. Effect of gamma irradiation, UV irradiation and hot water treatment on fungal growth and aflatoxin in mango fruits (Mangifera indica L.). Pak. J. Nutr. 2013, 12, 1050-1056. [CrossRef]

166. Shephard, G.S.; Vismer, H.F. Chapter 17: Effect of processing on the mycotoxin content in fruit juice. In Mycotoxins in Fruits and Vegetables; Barkai-Golan, R., Paster, N., Eds.; Elsevier: Berkeley, CA, USA, 2008; pp. 335-350.

167. Jiménez, M.; Logrieco, A.; Botalico, A. Occurrence and pathogenicity of Fusarium species in banana fruits. J. Phytopathol. 1993, 137, 214-220. [CrossRef] 
168. Li, C.; Zuo, C.; Deng, G.; Kuang, R.; Yang, Q.; Hu, C.; Sheng, O.; Zhang, S.; Ma, L.; Wei, Y.; et al. Contamination of bananas with beauvericin and fusaric acid produced by Fusarium oxysporum f. sp. cubense. PLoS ONE 2013, 8, e70226. [CrossRef] [PubMed]

169. Baiyewu, R.A.; Amusa, N.A.; Ayoola, O.A.; Babalola, O.O. Survey of the post harvest diseases and aflatoxin contamination of marketed pawpaw fruit (Carica papaya L.) in South Western Nigeria. African J. Agric. Res. 2007, 2, 178-181.

170. Zakaria, L.; Wan Chik, M.; Wai Heng, K.; Salleh, B. Fusarium species Associated with Fruit Rot of Banana (Musa spp.), Papaya (Carica papaya) and Guava (Psidium guajava). Malays. J. Microbiol. 2012, 8, 127-130. [CrossRef]

171. Abdallah, M.F.; Krska, R.; Sulyok, M. Mycotoxin contamination in sugarcane grass and juice: First report on detection of multiple mycotoxins and exposure assessment for aflatoxins B1 and G1 in humans. Toxins 2016, 8, 343. [CrossRef] [PubMed]

172. Yassihuyuk, N.; Kadakal, C.; Otag, M. Ergosterol and patulin contents of conventional and homemade red peppers and hot red peppers pastes. J. Food. Process. Technol. 2014, 5, 379. [CrossRef]

173. Ioi, J.D.; Zhou, T.; Tsao, R.; Marcone, M.F. Mitigation of patulin in fresh and processed foods and beverages. Toxins 2017, 9, 157. [CrossRef] [PubMed]

174. Ganzera, M.; Strum, S. Recent advances on HPLC/MS in medicinal plant analysis-An update covering 2011-2016. J. Pharm. Biomed. Anal. 2018, 147, 211-233. [CrossRef] [PubMed]

175. Zhang, L.; Dou, X.-W.; Zhang, C.; Logrico, A.F.; Yang, M.-H. A review of current methods for analysis of mycotoxins in herbal medicines. Toxins 2018, 10, 65. [CrossRef] [PubMed]

176. Wang, M.; Jiang, N.; Xian, H.; Wei, D.; Shi, L.; Feng, X. A single-step solid phase extraction for the simultaneous determination of 8 mycotoxins in fruits by ultra-high performance liquid chromatography tandem mass spectrometry. J. Chromatogr. A 2016, 1429, 22-29. [CrossRef] [PubMed]

177. La Barbera, G.; Capriotti, A.L.; Cavaliere, C.; Foglia, P.; Montone, C.M.; Chiozzi, R.Z.; Laganà, A. A Rapid Magnetic Solid Phase Extraction Method Followed by Liquid Chromatography-Tandem Mass Spectrometry Analysis for the Determination of Mycotoxins in Cereals. Toxins 2017, 9, 147. [CrossRef] [PubMed]

178. Granados-Chinchilla, F. Insights into the Interaction of Milk and Dairy Proteins with Aflatoxin $\mathrm{M}_{1}$. In Milk Proteins from Structure to Biological Properties and Health Aspects; Gigli, I., Ed.; IntechOpen Limited: London, UK, 2016; pp. 266-286. ISBN 978-953-51-2537-2.

179. Capriotti, A.L.; Cavaliere, C.; Foglia, P.; La Barbera, G.; Samperi, R.; Ventura, S.; Laganà, A. Mycoestrogen determination in cow milk: Magnetic solid-phase extraction followed by liquid chromatography and tandem mass spectrometry analysis. J. Sep. Sci. 2016, 39, 4794-4808. [CrossRef] [PubMed]

180. Socas-Rodríguez, B.; Herrera-Herrera, A.V.; Asencio-Ramos, M.; Harnández-Borges, J. Recent applications of carbon nanotube sorbents in analytical chemistry. J. Chromatogr. A 2014, 1357, 110-146. [CrossRef] [PubMed]

181. Herrero-LaTorre, C.; Barcela-García, J.; García-Martín, S.; Peña-Crecente, R.M.; Otárola-Jiménez, J. Magnetic solid-phase extraction using carbon nanotubes as sorbents: A review. Anal. Chim. Acta 2015, 892, 10-26. [CrossRef] [PubMed]

182. Dong, M.; Si, W.; Wang, W.; Bai, B.; Nie, D.; Song, W.; Zhao, Z.; Guo, Y.; Han, Z. Determination of type A trichothecenes in coix seed by magnetic solid-phase extraction based on magnetic multi-walled carbon nanotubes coupled with ultra-high performance liquid chromatography-tandem mass spectrometry. Anal. Bioanal. Chem. 2016, 408, 6823-6831. [CrossRef] [PubMed]

183. Liang, X.; Liu, S.; Wang, S.; Guo, Y.; Jiang, S. Carbon-based sorbents: Carbon nanotubes. J. Chromatogr. A 2014, 1357, 53-67. [CrossRef] [PubMed]

184. Li, J.; Deng, Y.; Liu, Y.; Ding, Z.; Li, Y.; Jin, Y. High Throughput Detections. Toxicol. Open Access 2017, 3, 131. [CrossRef]

185. Arroyo-Manzanares, N.; Huertas-Pérez, J.F.; García-Campaña, A.M.; Gámiz-Gracia, L. Mycotoxin Analysis: New Proposals for Sample Treatment. Adv. Chem. 2014, 2014, 547506. [CrossRef]

186. Berthiller, F.; Cramer, B.; Iha, M.H.; Krska, R.; Lattanzio, V.M.T.; MacDonald, S.; Malone, R.J.; Maragos, C.; Solfizzo, M.; Stranska-Zachariasova, M.; et al. Developments in mycotoxin analysis: An update for 2016-2017. World Mycotoxin J. 2018, 11, 5-31. [CrossRef]

187. Escrivá, L.; Oueslati, S.; Font, G.; Manyes, L. Alternaria Mycotoxins in Food and Feed: An Overview. J. Food Qual. 2017, 2017, 1569748. [CrossRef] 
188. Tölgyesi, Á.; Stroka, J.; Tamosiunas, V.; Zwickel, T. Simultaneous analysis of Alternaria toxins and citrinin in tomato: An optimised method using liquid chromatography-tandem mass spectrometry. Food Addit. Contam. Part A 2015, 32, 1512-1522. [CrossRef] [PubMed]

189. Da Cruz Cabral, L.; Terminiello, L.; Fernández Pinto, V.; Fog Nielsen, K.; Patriarca, A. Natural occurrence of mycotoxins and toxigenic capacity of Alternaria strains from mouldy peppers. Int. J. Food Microbiol. 2016, 236, 155-160. [CrossRef] [PubMed]

190. Santos, G.G.; Mattos, L.M.; Moretti, C.L. Quality and Occurrence of Mycotoxins in Tomato Products in the Brazilian Market. Enzym. Eng. 2016, 5, 3. [CrossRef]

191. Chen, A.J.; Tang, D.; Zhou, Y.Q.; Sun, D.S.; Li, X.J.; Wang, L.Z.; Gao, W.W. Identification of Ochratoxin A Producing Fungi Associated with Fresh and Dry Liquorice. PLoS ONE 2013, 8, e78285. [CrossRef] [PubMed]

192. Romero-González, R.; Frenich, A.G.; Vidal, J.L.; Aguilera-Luiz, M.M. Determination of ochratoxin A and T-2 toxin in alcoholic beverages by hollow fiber liquid phase microextraction and ultra high-pressure liquid chromatography coupled to tandem mass spectrometry. Talanta 2010, 82, 171-176. [CrossRef] [PubMed]

193. Maham, M.; Kiarostami, V.; Waqif-Husain, S.; Karami-Osboo, R.; Mirabolfathy, M. Analysis of Ochratoxin A in Malt Beverage Samples using Dispersive Liquid-Liquid Microextraction Coupled with Liquid Chromatography-Fluorescence Detection. Czech J. Food Sci. 2013, 31, 520-525. [CrossRef]

194. Meena, M.; Zehra, A.; Dubey, M.K.; Aamir, M.; Gupta, V.K.; Upadhyay, R.S. A Comparative Evaluation of Biochemical Changes in Tomato (Lycopersicon esculentum Mill.) Infected by Alternaria alternata and Its Toxic Metabolites (TeA, AOH, and AME). Front. Plant Sci. 2016, 7, 1408. [CrossRef] [PubMed]

195. Walravens, J.; Mikula, H.; Rychlik, M.; Asam, S.; Ediage, E.N.; Di Mavungu, J.D.; Van Landschoot, A.; Vanhaecke, L.; De Saeger, S. Development and validation of an ultra-high-performance liquid chromatography tandem mass spectrometric method for the simultaneous determination of free and conjugated Alternaria toxins in cereal-based foodstuffs. J. Chromatogr. A 2014, 1372, 91-101. [CrossRef] [PubMed]

196. Liu, L.; Jin, H.; Sun, L.; Ma, S.; Lin, R. Determination of Aflatoxins in Medicinal Herbs by High-performance Liquid Chromatography-Tandem Mass Spectrometry. Phytochem. Anal. 2012, 23, 469-476. [CrossRef] [PubMed]

197. Sun, S.; Yao, K.; Zhao, S.; Zheng, P.; Wang, S.; Zeng, Y.; Liang, D.; Ke, Y.; Jiang, H. Determination of aflatoxin and zearalenone analogs in edible and medicinal herbs using a group-specific immunoaffinity column coupled to ultra-high performance liquid chromatography with tandem mass spectrometry. J. Chromatogr. A 2018, 1092, 228-236. [CrossRef] [PubMed]

198. Monbaliu, S.; Wu, A.; Zhang, D.; Van Peteghem, C.; De Saeger, S. Multimycotoxin UPLC-MS/MS for Tea, Herbal Infusions and the Derived Drinkable Products. J. Agric. Food Chem. 2010, 58, 12664-12671. [CrossRef] [PubMed]

199. Pallarés, N.; Font, G.; Mañes, J.; Ferrer, E. Multimycotoxin LC-MS/MS analysis in tea beverages after dispersive liquid-liquid microextraction (DLLME). J. Agric. Food Chem. 2017, 65, 10282-10289. [CrossRef] [PubMed]

200. Miró-Abella, E.; Herrero, P.; Canela, N.; Arola, L.; Borrull, F.; Ras, R.; Fontanals, N. Determination of mycotoxins in plant-based beverages using QuEChERS and liquid chromatography-tandem mass spectrometry. Food Chem. 2017, 229, 366-372. [CrossRef] [PubMed]

201. Vaclavik, L.; Vaclavikova, M.; Begley, T.H.; Krynitsky, A.J.; Rader, J.I. Determination of Multiple Mycotoxins in Dietary Supplements Containing Green Coffee Bean Extracts Using Ultrahigh-Performance Liquid Chromatography-Tandem Mass Spectrometry (UHPLC-MS/MS). J. Agric. Food Chem. 2013, 61, 4822-4830. [CrossRef] [PubMed]

202. Juan, C.; Mañes, J.; Font, G.; Juan-García, A. Determination of mycotoxins in fruit berry by-products using QuEChERS extraction method. LWT Food Sci. Technol. 2017, 86, 344-351. [CrossRef]

203. Flores-Flores, M.E.; González-Peñas, E. Analysis of Mycotoxins in Peruvian Evaporated Cow Milk. Beverages 2018, 4, 34. [CrossRef]

204. Lippolis, V.; Maragos, C. Fluorescence polarisation immunoassays for rapid, accurate and sensitive determination of mycotoxins. World Mycotoxin J. 2014, 7, 479-489. [CrossRef]

205. Anfossi, L.; Baggiani, C.; Giovannoli, C.; D'Arco, G.; Giraudi, G. Lateral-flow immunoassays for mycotoxins and phycotoxins: A review. Anal. Bioanal. Chem. 2013, 405, 467-480. [CrossRef] [PubMed] 
206. Sajid, M.; Kawde, A.-N.; Daud, M. Designs, formats and applications of lateral flow assay: A literature review. J. Saudi Chem. Soc. 2015, 19, 689-705. [CrossRef]

207. Tripathi, P.; Upadhyay, N.; Nara, S. Recent advancements in lateral flow immunoassays: A journey for toxin detection in food. Crit. Rev. Food Sci. Nutr. 2017, 58, 1715-1734. [CrossRef] [PubMed]

208. Suman, M.; Poms, R. Foreword: Rapid methods for mycotoxin detection. World Mycotoxin J. 2014, 7, 401-405.

209. Joshi, S.; Annida, R.M.; Zuilhof, H.; van Beek, T.A.; Nielen, M.W.F. Analysis of Mycotoxins in Beer Using a Portable Nanostructured Imaging Surface Plasmon Resonance Biosensor. J. Agric. Food Chem. 2016, 64, 8263-8271. [CrossRef] [PubMed]

210. Peters, J.; van Dam, R.; van Doom, R.; Katerere, D.; Berthiller, F.; Haasnoot, W.; Nielen, M.W.F. Mycotoxin profiling of 1000 beer samples with a special focus on craft beer. PLoS ONE 2017, 12, e0185887. [CrossRef] [PubMed]

211. Anfossi, L.; Giovannoli, C.; Giraudi, G.; Biagioli, F.; Passini, C.; Baggiani, C. A Lateral Flow Immunoassay for the Rapid Detection of Ochratoxin A in Wine and Grape Must. J. Agric. Food Chem. 2012, 60, 11491-11497. [CrossRef] [PubMed]

212. Anfossi, L.; Baggiani, C.; Giovannoli, C.; Giraudi, G. Lateral Flow Immunoassays for Aflatoxins B and $\mathrm{G}$ and for Aflatoxin $\mathrm{M}_{1}$. In Aflatoxins-Recent Advances and Future Prospects; Razzaghi-Abyaneh, M., Ed.; IntechOpen Limited: London, UK, 2013; pp. 315-339. ISBN 978-953-51-0904-4.

213. Mataboro, E.; Ishimwe, N.; Uwimbabazi, E.; Lee, B.H. Current Immunoassay Methods for the Rapid Detection of Aflatoxin in Milk and Dairy Products. Compr. Rev. Food Sci. Food Saf. 2017, 16, 808-820. [CrossRef]

214. Song, S.; Liu, N.; Zhao, Z.; Ediage, E.N.; Wu, S.; Sun, C.; De Saeger, S.; Wu, A. Multiplex Lateral Flow Immunoassay for Mycotoxin Determination. Anal. Chem. 2014, 86, 4995-5001. [CrossRef] [PubMed]

215. Man, Y.; Liang, G.; Jia, F.; Li, A.; Fu, H.; Wang, M.; Pan, L. Development of an Immunochromatographic Strip Test for the Rapid Detection of Alternariol Monomethyl Ether in Fruit. Toxins 2017, 9, 152. [CrossRef] [PubMed]

216. Kong, D.; Liu, L.; Song, S.; Zhng, Q.; Wu, X.; Kuang, H. Rapid detection of tenuazonic acid in cereal and fruit juice using a lateral-flow immunochromatographic assay strip. Food Agric. Immunol. 2017, 28, 1293-1303. [CrossRef]

217. Urusov, A.E.; Zherdev, A.V.; Petrakova, A.V.; Sadykhov, E.G.; Koroleva, O.V.; Dzantiev, B.N. Rapid Multiple Immunoenzyme Assay of Mycotoxins. Toxins 2015, 7, 238-254. [CrossRef] [PubMed]

218. Li, W.; Powers, S.; Dai, S.Y. Using commercial immunoassay kits for mycotoxins: 'joys and sorrows'? World Mycotoxin J. 2014, 7, 417-430. [CrossRef]

219. O'Farrell, B. Lateral Flow Immunoassay Systems: Evolution from the Current State of the Art to the Next Generation of Highly Sensitive, Quantitative Rapid Assays. In The Immunoassay Handbook-Theory and Applications of Ligand Binding, ELISA and Related Techniques, 4th ed.; Wild, D., Ed.; Elsevier Science: Amsterdam, The Netherlands, 2013; pp. 90-107. ISBN 978-008-09-7037-0.

220. Man, Y.; Liang, G.; Li, A.; Pan, L. Recent Advances in Mycotoxin Determination for Food Monitoring via Microchip. Toxins 2017, 9, 324. [CrossRef] [PubMed]

221. Ngundi, M.M.; Shriver-Lake, L.C.; Moore, M.H.; Lassman, M.E.; Ligler, F.S.; Taitt, C.R. Array Biosensor for Detection of Ochratoxin A in Cereals and Beverages. Anal. Chem. 2005, 77, 148-154. [CrossRef] [PubMed]

222. Karczmarczyk, A. Development of Biosensors for Mycotoxins Detection in Food and Beverages. Ph.D. Thesis, Universität Regensburg, Regensburg, Germany, 2017.

223. Xu, L.; Zhang, Z.; Zhang, Q.; Li, P. Mycotoxin Determination in Foods Using Advanced Sensors Based on Antibodies or Aptamers. Toxins 2016, 8, 239. [CrossRef] [PubMed]

224. Tomita, Y.; Morita, Y.; Suga, H.; Fujiwara, D. DNA module platform for developing colorimetric aptamer sensors. BioTechniques 2016, 60, 285-292. [CrossRef] [PubMed]

225. Mahdavi, R.; Khorrami, S.A.H.; Jabbari, M.V. Evaluation of Ochratoxin A Contamination in Non Alcoholic Beers in Iran. Res. J. Biol. Sci. 2007, 2, 546-550.

226. Heussner, A.H.; Ausländer, S.; Dietrich, D.R. Development and Characterization of a Monoclonal Antibody against Ochratoxin B and Its Application in ELISA. Toxins 2010, 2, 1582-1594. [CrossRef] [PubMed]

227. Wang, J.; Mukhtar, H.; Ma, L.; Pang, Q.; Wang, X. VHH Antibodies: Reagents for Mycotoxin Detection in Food Products. Sensors 2018, 18, 485. [CrossRef] [PubMed] 
228. de Nijs, M.; Mengelers, M.J.B.; Boon, P.E.; Heyndrickx, E.; Hoogenboom, L.A.P.; Lopez, P.; Mol, H.G.J. Strategies for estimating human exposure to mycotoxins via food. World Mycotoxin J. 2016, 9, 831-845. [CrossRef]

229. Baker, R.C.; Ford, R.M.; Helander, M.E.; Marecki, J.; Natarajan, R.; Ray, B. Framework for Managing Mycotoxin Risks in the Food Industry. J. Food Prot. 2014, 77, 2181-2188. [CrossRef] [PubMed]

230. Van de Brug, F.J.; Lucas Luijckx, N.B.; Cnossen, H.J.; Houben, G.F. Early signals for emerging food safety risks: From past cases to future identification. Food Control 2014, 39, 75-86. [CrossRef]

231. Costa, M.C.; Goumperis, T.; Andresson, W.; Badiola, J.; Ooms, W.; Pongolini, S.; Saegerman, C.; Jurkovic, M.; Tuominen, P.; Tsigarida, E.; et al. Risk identification in food safety: Strategy and outcomes of the EFSA emerging risks exchange network (EREN), 2010-2014. Food Control 2017, 73, 255-264. [CrossRef]

232. Freire, L.; Sant'Ana, A.S. Modified mycotoxins: An updated review on their formation, detection, occurrence, and toxic effects. Food Chem. Toxicol. 2018, 111, 189-205. [CrossRef] [PubMed]

233. Kovač, M.; Šubarić, D.; Bulaić, M.; Kovač, T.; Šarkanj, B. Yesterday masked, today modified; what do mycotoxins bring next? Arh Hig Rada Toksikol. 2018, 69, 169-214. [CrossRef] [PubMed]

234. Alexander, J.; Bignmi, M.; Brüschweiler, B.J.; Rose, M.D. Risks for animal health related to the presence of fumonisins, their modified forms and hidden forms in feed. EFSA J. 2018, 16, 5242.

235. Medina, Á.; Rodríguez, A.; Magan, N. Climate change and mycotoxigenic fungi: Impacts on mycotoxin production. Curr. Opin. Food Sci. 2015, 5, 99-104. [CrossRef]

236. Baranyi, N.; Kocsubé, S.; Varga, J. Aflatoxins: Climate change and biodegradation. Curr. Opin. Food Sci. 2015, 5, 60-66. [CrossRef]

237. Medina, Á.; Akbar, A.; Baazeem, A.; Rodriguez, A.; Magan, N. Climate change, food security and mycotoxins: Do we know enough? Fungal Biol. Rev. 2017, 31, 143-145. [CrossRef]

238. Moretti, A.; Pascale, M.; Logrieco, A.F. Mycotoxin risks under a climate change scenario in Europe. Trends Food Sci. Technol. 2018, in press. [CrossRef]

239. Van de Perre, E. Farm to Fork Risk Assessment of Emerging Mycotoxins in Fresh Produce: The Case of Tomato Considering Climate Change. Ph.D. Thesis, Ghent University, Gent, Belgium, 2014.

240. Vaquera, S.; Patriarca, A.; Fernández Pinto, V. Influence of environmental parameters on mycotoxin production by Alternaria arborescens. Int. J. Food Microbiol. 2016, 219, 44-49. [CrossRef] [PubMed]

241. Marvin, H.J.P.; Kleter, G.A.; Van der Fels-Klerx, H.J.; Noordam, M.Y.; Franz, E.; Willems, D.J.M.; Boxall, A. Proactive systems for early warning of potential impacts of natural disasters on food safety: Climate-change-induced extreme events as case in point. Food Control 2013, 34, 444-456. [CrossRef]

242. Rahmianna, A.A.; Purnomo, J.; Yusnawan, E. Assessment of Groundnut Varietal Tolerant to Aflatoxin Contamination in Indonesia. Procedia Food Sci. 2015, 3, 330-339. [CrossRef]

243. Torre, A.M.; Barros, G.G.; Palacios, S.A.; Chulze, S.N.; Battiani, P. Review on pre- and post-harvest management of peanuts to minimize aflatoxin contamination. Food Res. Int. 2014, 62, 11-19. [CrossRef]

244. Panjak, S.K.; Shi, H.; Keener, K.M. A review of novel physical and chemical decontamination technologies for aflatoxin in food. Trends Food Sci. Technol. 2018, 71, 73-83.

245. Chulze, S.N.; Palazzini, J.M.; Torres, A.M.; Barros, G.; Ponsone, M.L.; Geisen, R.; Schmidt-Heydt, M.; Köhl, J. Biological control as a strategy to reduce the impact of mycotoxins in peanuts, grapes and cereals in Argentina. Food Addit. Contam. Part A 2015, 32, 471-479. [CrossRef] [PubMed]

246. Udomkan, P.; Wiredu, A.N.; Nagle, M.; Müller, J.; Vanlauwe, B.; Bandyopadhyay, R. Innovative technologies to manage aflatoxins in foods and feeds and the profitability of application-A review. Food Control 2017, 76, 127-138. [CrossRef] [PubMed]

247. Bhatnagar-Mathur, P.; Sunkara, S.; Bhatnagar-Panwar, M.; Waliyar, F.; Sharma, K.K. Biotechnological advances for combating Aspergillus flavus and aflatoxin contamination in crops. Plant Sci. 2015, 234, 119-132. [CrossRef] [PubMed]

248. Fountain, J.C.; Khera, P.; Yang, L.; Nayak, S.N.; Scully, B.T.; Lee, R.D.; Chen, Z.-Y.; Kemerait, R.C.; Varshney, R.K.; Guo, B. Resistance to Aspergillus flavus in maize and peanut: Molecular biology, breeding, environmental stress, and future perspectives. Crop J. 2015, 3, 229-237. [CrossRef]

249. Scussel, V. Mycotoxins and fungi food decontamination by GRAS methods. Food Process. Technol. $2016,7$. [CrossRef]

250. Shah, L.; Ali, A.; Yahya, M.; Zhu, Y.; Wang, S.; Si, H.; Rahman, H.; Ma, C. Integrated control of Fusarium head blight and deoxynivalenol mycotoxin in wheat. Plant Pathol. 2017, 67, 532-548. [CrossRef] 
251. Granados-Chinchilla, F. A Focus on Aflatoxin in Feedstuffs: New Developments in Analysis and Detection, Feed Composition Affecting Toxin Contamination, and Interdisciplinary Approaches to Mitigate It. In Aflatoxin-Control, Analysis, Detection and Health Risks; Abdulra'uf, L.B., Ed.; InTechOpen: London, UK, 2017; pp. 251-280. ISBN 978-953-51-3458-9.

252. Juvonen, R.; Virkajärvi, V.; Priha, O.; Laitila, A. Microbiological Spoilage and Safety Risks in Non-Beer Beverages; VTT Technical Research Centre of Finland: Vuorimiehentie, Finland, 2011; pp. 37-44. ISBN 978-951-38-7786-6.

253. Rawat, S. Food Spoilage: Microorganisms and their prevention. Asian J. Plant Sci. Res. 2015, 5, 47-56.

254. Kregiel, D. Health Safety of Soft Drinks: Contents, Containers, and Microorganisms. BioMed Res. Int. 2015, 2015, 128697. [CrossRef] [PubMed]

255. Pitt, J.L.; Hocking, A.D. Fungi and Food Spoilage, 3rd ed.; Springer: New York, NY, USA, 2009; pp. 401-416. ISBN 978-0-387-92207-2.

256. Wu, F.; Stacy, S.L.; Kensler, T.W. Global Risk Assessment of Aflatoxins in Maize and Peanuts: Are Regulatory Standards Adequately Protective? Toxicol. Sci. 2013, 135, 251-259. [CrossRef] [PubMed]

257. Kang'ethe, E.K.; Korhonen, H.; Marimba, K.A.; Nduhiu, G.; Mungatu, J.K.; Okoth, S.A.; Joutsjoki, V.; Wamae, L.W.; Shalo, P. Management and mitigation of health risks associated with the occurrence of mycotoxins along the maize value chain in two counties in Kenya. Food Qual. Saf. 2017, 1, 268-274. [CrossRef]

258. Adetunji, M.C.; Atanda, O.O.; Ezekiel, C.N. Risk Assessment of Mycotoxins in Stored Maize Grains Consumed by Infants and Young Children in Nigeria. Children 2017, 4, 58. [CrossRef] [PubMed]

259. Assunção, R.; Silva, M.J.; Alvito, P. Challenges in risk assessment of multiple mycotoxins in food. World Mycotoxin J. 2016, 9, 791-811. [CrossRef]

260. International Agency for Research on Cancer (IARC). Practical approaches to control mycotoxins. In Improving Public Health Thorugh Mycotoxin Control; Pitt, J.I., Wild, C.P., Baan, R.A., Gelderblom, W.C.A., Miller, J.D., Riley, R.T., Wu, F., Eds.; IARC: Lyon, France, 2012; pp. 131-146. ISBN 978-92-832-2158-6.

261. United States Food and Drug Administration (US FDA). Juice HACCP and the FDA Food Safety Modernization Act: Guidance for Industry. Available online: https://www.fda.gov/downloads/ Food/GuidanceRegulation/GuidanceDocumentsRegulatoryInformation/UCM569777.pdf (accessed on 25 September 2018).

262. Ozturkoglu-Budak, S. A model for implementation of HACCP system for prevention and control of mycotoxins during the production of red dried chili pepper. Food Sci. Technol. 2017, 37, 24-29. [CrossRef]

263. Gil, L.; Ruiz, P.; Font, G.; Manyes, L. An overview of the applications of hazards analysis and critical control point (HACCP) system to mycotoxins. Rev. Toxicol. 2016, 33, 50-55.

264. Kristina, S.; Wijaya, B.M. Risk management for food and beverage industry using Australia/New Zealand 4360 Standard. IOP Conf. Ser. Mater. Sci. Eng. 2017, 277, 012025. [CrossRef]

265. Akbari, P.; Braber, S.; Varasteh, S.; Alizadeh, A.; Garssen, J.; Fink-Gremmels, J. The intestinal barrier as an emerging target in the toxicological assessment of mycotoxins. Arch. Toxicol. 2017, 91, 1007-1029. [CrossRef] [PubMed]

266. Abreu de Assunção, R.M. Children Exposure to Multiple Mycotoxins through Food Consumption: A Holistic Approach for Risk Assessment. Ph.D. Thesis, Universidade de Évora, Évora, Portugal, 2017.

267. Benedict, K.; Chiller, T.M.; Mody, R.K. Invasive Fungal Infections Acquired from Contaminated Food or Nutritional Supplements: A Review of the Literature. Foodborne Pathog. Dis. 2016, 13, 343-349. [CrossRef] [PubMed]

268. Vieira, N.O.; Peres, A.; Aquino, V.R.; Pasqualatto, A.C. Drinking yerba mate infusion: A potential risk factor for invasive fungal diseases? Transpl. Infect. Dis. 2010, 12, 565-569. [CrossRef] [PubMed]

269. Chhonker, S.K.; Rawat, D.; Naik, R.A.; Koiri, R.K. An Overview of Mycotoxins in Human Health with Emphasis on Development and Progression of Liver Cancer. Clin. Oncol. 2018, 3, 1408.

270. Torres, O.; Matute, J.; Eglineau Waes, J.; Maddox, J.R.; Gregory, S.G.; Ashley-Kock, A.E.; Showker, J.L.; Voss, K.A.; Riley, R.T. Human health implications from co-exposure to aflatoxins and fumonisins in maize based foods in Latin America: Guatemala as a case study. World Mycotoxin J. 2015, 8, 143-159. [CrossRef]

(C) 2018 by the authors. Licensee MDPI, Basel, Switzerland. This article is an open access article distributed under the terms and conditions of the Creative Commons Attribution (CC BY) license (http:/ / creativecommons.org/licenses/by/4.0/). 